\title{
An urban political ecology of Bangkok's awful traffic congestion
}

\author{
Danny Marks ${ }^{1}$ \\ Dublin City University, Ireland
}

\begin{abstract}
Urban political ecology (UPE) can contribute important insights to examine traffic congestion, a significant social and environmental problem underexplored in UPE. Specifically, by attending to power relations, the production of urban space, and cultural practices, UPE can help explain why traffic congestions arises and persists but also creates inequalities in terms of environmental impacts and mobility. Based on qualitative research conducted in 2018, the article applies a UPE framework to Bangkok, Thailand, which has some of the world's worst congestion in one of the world's most unequal countries. The city's largely unplanned and uneven development has made congestion worse in a number of ways. Further, the neglect of public transport, particularly the bus system, and the highest priority given to cars has exacerbated congestion but also reflects class interests as well as unequal power relations. Governance shortcomings, including fragmentation, institutional inertia, corruption, and frequent changes in leadership, have also severely hindered state actors to address congestion. However, due to the poor's limited power, solutions to congestion, are post-political and shaped by elite interests. Analyses of congestion need to consider how socio-political relations, discourses, and a city's materiality shape outcomes.
\end{abstract}

Key Words: urban transport governance, Bangkok traffic congestion, urban political ecology, Thailand political economy, Bangkok's bus system

\section{Résumé}

L'écologie politique urbaine (EPU) peut apporter des informations importantes pour examiner la congestion routière, un problème social et environnemental important sous-exploré dans l'EPU. Plus précisément, en s'occupant des relations de pouvoir, de la production d'espace urbain et des pratiques culturelles, l'EPU peut aider à expliquer pourquoi les embouteillages surviennent et persistent mais créent également des inégalités en termes d'impacts environnementaux et de mobilité. Sur la base d'une recherche qualitative menée en 2018, l'article applique un cadre d'EPU à Bangkok, en Thaïlande, qui connaît l'une des pires congestions au monde dans l'un des pays les plus inégaux du monde. Le développement largement imprévu et inégal de la ville a aggravé la congestion de plusieurs manières. En outre, la négligence des transports publics, en particulier les bus, et la priorité la plus élevée accordée aux voitures ont exacerbé la congestion, mais reflètent également des intérêts de classe ainsi que des relations de pouvoir inégales. Les lacunes de la gouvernance, notamment la fragmentation, l'inertie institutionnelle, la corruption et les changements fréquents de direction, ont également gravement empêché les acteurs étatiques de s'attaquer à la congestion. Cependant, en raison du pouvoir limité des citadins pauvres, les solutions à la congestion sont «post-politiques» et façonnées par les intérêts des élites. Les analyses de la congestion doivent considérer comment les relations sociopolitiques, les discours et la matérialité d'une ville contribuent à la situation actuelle.

Mots clés: gouvernance des transports urbains, embouteillage à Bangkok, écologie politique urbaine, économie politique thaïlandaise, système de bus de Bangkok

\section{Resumen}

La ecología política urbana (UPE) puede aportar ideas importantes para examinar la congestión del tráfico, un importante problema social y ambiental poco explorado en la UPE. Específicamente, al atender las

\footnotetext{
${ }^{1}$ Dr. Danny Marks, Assistant Professor, School of Law and Government, Dublin City University, Dublin, Ireland. Email: danny.marks "at" dcu.edu. I would like to thank Thareerat Laohabut for assisting with the data collection. I am grateful to Panit Pujinda (Chulalongkorn University), Toby Carroll (City University of Hong Kong) and Eli Elinoff (Victoria University of Wellington) for their helpful suggestions and to Simon Batterbury for his assistance throughout the review process.
} 
relaciones de poder, la producción de espacio urbano y las prácticas culturales, la UPE puede ayudar a explicar por qué surge y persiste la congestión del tráfico, pero también crea desigualdades en términos de impactos ambientales y movilidad. Basado en una investigación cualitativa realizada en 2018, el artículo aplica un marco UPE a Bangkok, Tailandia. La ciudad tiene la peor congestión del mundo, en uno de los países más desiguales del mundo. El desarrollo desigual y no planificado de la ciudad ha empeorado la congestión de varias maneras. Además, el descuido del transporte público, particularmente los autobuses, y la alta prioridad dada a los automóviles ha exacerbado la congestión. También refleja los intereses de clase y las relaciones desiguales de poder. Las deficiencias de gobernanza también obstaculizan severamente a los actores estatales para abordar la congestión. Hay fragmentación de responsabilidades, inercia institucional, corrupción y cambios frecuentes en el liderazgo. Sin embargo, debido al poder limitado de los pobres urbanos, las soluciones a la congestión son 'pospolíticas' y están moldeadas por los intereses de las élites. Los análisis de congestión deben considerar cómo las relaciones sociopolíticas, los discursos y la materialidad de una ciudad contribuyen a la situación actual.

Palabras clave: gobernanza del transporte urbano, congestión del tráfico de Bangkok, ecología política urbana, economía política de Tailandia, sistema de autobuses de Bangkok

抽象:

交通擠塞是一個指標性的社會環境問題, 都市政治生態學 (UPE) 對於研究交通擠塞有重要的啟發, 卻在此方面著墨不多。具體而言, 都市政治生態學可以特別從權力關係、城市空間生產以及文化習 慣方面, 解釋交通擠塞形成及持續的成因、以至如何製造環境影響的不平等及流動的不平等。根據 2018 年一項質性研究, 其中應用都市政治生態學框架, 以分析泰國曼谷作為全球最差的擠塞城市同 時泰國被列為全球最不平等的國家之一。城市嚴重缺乏規劃和失衡發展, 往往在多方面惡化擠塞問 題。此外, 以私家車優先, 而忽視公共交通如巴士, 不單加劇擠塞情況, 更反映階級利益以至不平 等的權力關係。管治失誤包括部門分裂、制度慣性和朝令夕改的政治領導也嚴重窒礙執權者處理擠 塞問題。反過來看, 弱勢的政經權力受限, 因此擠塞問題往往交由精英受益者形塑, 並形成後政治 ( Post-political) 。擠塞問題的分析必須考慮政治社會關係、話語權和城市材料性如何形塑結果。 矣键词: 城市交通治理, 曼谷交通拥堵, 都市政治生態學，泰国政治经济，曼谷的巴士系统

\section{บทคัดย่อ:}

นิเวศวิทยาการเมืองของเมือง (UPE) ช่วยให้เกิดความรู้ ความเข้าใจที่สำคัญ ในการตรวจสอบสภาพการจราจรที่คับคั่ง ปัญหาสังคมและสิ่งแวดล้อมที่สำคัญที่ยังไม่ได้รับการวิเคราะห์โดยนิเวศวิทยาการูเมืองของเมือง (UPE) โดยเฉพาะอย่างยิ่งเมื่อมีความสัมพันธ์เชิงอำนาจ ซึ่งมีผลมาจากการผลผลิตในพื้นที่เมืองและวัฒนธรรมการปฏิบัติ นิเวศวิทยาการเมืองของเมือง (UPE) สามารถช่วยอธิบายว่าเหตุใดความแออัดของการจราจรจึงเกิดขึ้นและคงอยู่ และสร้างความไม่เท่าเทียมกันในแง่ของผลกระทบต่อสิ่งแวดล้อมและการเดินทาง จากการวิจัยเชิงคุณภาพที่ดำเนิ้นการในปี พ. ศ. 2561 โดยใช้กรอบแนวคิดนิเวศวิทยาการเมืองของเมือง (UPE) กับกรุงเทพมหานครเมืองหลวงของประเทศไทย ซึ่งเป็นหนึ่งในเมืองที่มีความแออัดที่สุดของโลก พบว่า การพัฒนาที่ขาดวางแผนของแมืองทำปัญหายิ่งเลวร้ายลงในหลายๆ ด้าน นอกจากนี้การละเลยระบบขนส่งสาธารณะโดยเฉพาะอย่างยิ่ง ระบบรถเมล์และให้ความสำคัญกับรถยนต์สวนตัวทำให้เกิดแออัดมากขึ้น ยังสะท้อนถึงความสนใจปัญหาและความสัมพันธ์ด้านอำนาจที่ไม่เท่าเทียมกัน ข้อเสียด้านการกำกับดูแลรวมถึงการแยกส่วนด้านการบริหารและเฉื่อยช้าของหน่วยงานและการเปลี่ยนแปลงผู้นำบ่อยๆทำใ ห้เกิดการขัดขวางอำนาจรัฐในการแก้ปัญหาการจราจรแออัดอย่างรุนแรง อย่างไรก็ตามเนื่องจากอำนาจที่มีอยู่อย่างจำกัดของคนจน การแก้ปัญหาความแออัดจึงเป็นเรื่องของชนชั้นสูง

คำสำคัญ: การกำกับดูแลการขนสงในเมือง, การจราจรติดขัดในกรุงเทพ, นิเวศวิทยาการเมืองของเมือง, เศรษฐกิจการเมืองไทย, ระบบรถโดยสารของกรุงเทพ

\section{Introduction}

Traffic congestion is undoubtedly a major challenge of our time, and it presents considerable stress to the environment and to society. Foremost, as conventionally powered vehicles spend more time on the road, idling or crawling, they use more fuel and also cause greenhouse emissions to rise (Bharadwaj, Ballare and Chandel 2017). Currently, urban transportation accounts for approximately $20 \%$ of total emissions and this number is expected to rise (Ferrer, Thomé and Scavarda 2018). Moreover, congestion degrades air quality. 
Socially, it reduces productivity, increases transports costs, and the risk of accidents, and raises stress levels (Bharadwaj, Ballare and Chandel 2017).

However, policymakers have devoted little attention to reducing emissions through addressing congestion. Nor have political scientists, political economists, or political geographers held this sector to the same level of scrutiny as other sectors, such as health, education, water, and land (Klopp 2012; Khayesi et al. 2017; Kębłowski and Bassens 2018; Legacy 2016; Mattioli et al. 2020). Most research on traffic congestion has been "technical" and "apolitical" (Mattioli et al. 2020: 486) and been conducted primarily by engineers and economists. These researchers often use techniques such as the four-stage transport-land use model and statistical modelling of travel behavior (Khayesi et al. 2017). The consequence is that the political economy affecting transport outcomes is analyzed less within conventional transport research approaches ${ }^{2}$ (Marsden and Reardon 2017). However congestion is not merely about transport modes and movements, but also about politics, institutions, discourses, cultural practices, and power (Schwanen 2016). It requires an appreciation of the social, political and geographical contexts within which transportation operates. As Lefebvre (1991) argues, transport is about the right to public spaces in cities and who can or cannot access those spaces (also see Koglin and Rye 2014). There is therefore a pressing need to "re-connect urban transport with political economic considerations" (Kębłowski, Van Criekingen and Bassens 2019: 24).

In response, I argue that urban political ecology (UPE) provides a useful framework to address this need. With a strong Marxist leaning, UPE originates from geographers perceiving landscapes and infrastructures of cities "as historical products of human-nature interactions" (Keil 2003: 724) which often are "controlled and manipulated and serve the interests of the elite at the expense of marginalized populations" (Swyngedouw and Heynen 2003: 902). The urban element of UPE developed from the work of David Harvey and Henri Lefebvre. In his seminal work, Social justice and the city, Harvey begins with the position that the city is a tangible, built environment but also a social product (Harvey 1973). He also characterizes cities as landscapes of power. Lefebvre calls urban environments "second nature" and a socially produced space that is often uneven and socially unjust (Lefebvre 1976). Analyzing the city from a political economy perspective, Swyngedouw focused on the "power geometries and social actors who carry them out" because they determine who can gain access to or control resources or other components of the environment (2004: 23). Given the key role of the state in governing infrastructure and access to resources, UPE focuses on the role of the state, arguing that it is not an impartial, monolithic actor but instead comprises many different actors with differing interests (Collins 2010).

Urban political ecologists also insist that the 'materiality' of cities should be central to any study. Analyses of social power, and relations, economic transactions, policy discourses, and cultural habits should be linked to their effects on urbanization, natural resources, and thus the 'material' environment (Monstadt 2009). This approach conceives of an urban landscape as an interconnected ecological system in which anthropogenic land use has affected the bio-physical of the natural environment. Under this approach, urbanization is not seen to displace nature but rather "rework" nature (Murray 2009).

A key concept in UPE is metabolism, which refers to the ways in which energy, waste, and other materials are transformed and circulated by urbanization and capitalist processes to produce and reproduce urban life (Swyngedouw 2006). The concept of metabolic circulation and the ways in which it is a socially mediated process mobilizing numerous actors (Heynen, Kaika and Swyngedouw 2006) can usefully be applied to urban transportation. Taking this further, one type of the heterogeneous assemblage forming around 'metabolic vehicles' is traffic congestion and its deleterious, uneven effects (ibid.). A UPE framework therefore examines the ways in which metabolisms are mobilized by and for specific people and interests, and the subsequent socio-environmental transformations. Further, the post-structuralist turn in UPE also pays attention to the ways in which discourses and cultural practices shape the social construction of the

\footnotetext{
${ }^{2}$ Marsden and Reardon (2017) analyzed 100 articles from two leading transportation policy journals. They found that only $10 \%$ engaged with policy debates and two-thirds did not engage with real policies or policymakers and only conducted quantitative analysis. They concluded that future research needs to "pay greater attention to context, politics, power, resources and legitimacy" (p. 249).
} 
environment (Véron 2006). Given, urban transportation's rising contribution to climate change and air pollution but also the key role of power, discourses, and conflict in shaping urban transportation outcomes, particularly congestion, understanding urban transportation systems through a UPE framework is a valuable and perhaps necessary undertaking.

Nonetheless and surprisingly, similar to the literature on urban air (e.g., Graham 2015; Véron 2006), only a small body of literature has used UPE to analyze urban transport (e.g. Behrsin and Benner 2017). Monstadt (2009) has called for more studies to address this gap. I seek to take this argument further by arguing that UPE is useful for analyzing urban traffic congestion. To unpack congestion's complexity, including the underlying drivers and power geometries behind it, many components need to be understood, including a city's materiality and the spatiality of transportation nodes; the current means of private and public transport and the reasons why the latter have failed to alleviate congestion; daily, cultural practices contributing to congestion; and the actions, power relations, and incentives of state actors involved in urban transport.

I seek to make this case by applying an UPE analysis to Bangkok, ranked in 2018 by the navigation company TomTom, as having the world's worst traffic congestion (Fickling 2018). In January and February 2020, Bangkok also ranked among the top ten cities globally in terms of worst air quality (Figure 1) (Chankaew and Setboonsarng 2020). From January-July 2020, air pollution caused approximately 6,800 deaths and economic losses of 81.4 billion baht (US\$2.58 billion) (Burton 2020). It is not surprising therefore that transport contributes greatly to Bangkok's overall carbon emissions: $25 \%$ of its emissions come from this sector, higher than the global average. Further, a 2011 study found that Bangkok's transportation sector emits at least twice as much carbon per capita than that of New York, London, and Mexico City (Croci, Melandri and Molteni 2011). Concurrently, within this sector there exists highly unequal carbon and air pollution footprints and levels of mobility between low-income and middle- and upper-income Bangkok residents since the former either work near their residences or travel to work using public transportation, in particular on buses, or low-emitting motorcycles while the majority of the latter drive private cars (Pujinda and Yupho 2017). Only a small percentage of trips are taken using the city's two mass rail systems: the Skytrain and subway.

Bangkok is the capital of Thailand, a country of considerate economic and political inequality. In terms of income inequality, it is the sixth most unequal country globally (Phongpaichit and Baker 2015). The top $1 \%$ of Thais capture about half of all income from investment and rents. Moreover, these wealth inequalities wealth bred "other kinds of inequality which became built into the structure of society and the attitudes of its members", including privileged access to justice and political power (Phongpaichit and Baker 2015: 17). Consequently, the Thai political system is an oligarchy in which "the powerful have never been conclusively undermined" (ibid.:19). Thailand's high degree of political and economic inequality is particularly stark in Bangkok (Marks, Connell and Ferrara 2020). Despite the significant amount of literature on Thailand's political economy, none has extended to an examination of ways in which it affects Bangkok's transport.

While there have been studies of Bangkok's transportation governance and its congestion, there are only a few and most are dated (e.g., Daniere 1995; Bae and Suthiranart 2003; Wu and Pojani 2016). Therefore, I seek to add to this literature. To collect data, I conducted interviews with 21 key actors from June-August 2018. The actors fell under five categories: government, private sector, media, NGOs, and think tanks. ${ }^{3}$ I asked them about the causes of Bangkok's persistent and widespread traffic as well as the relationships between different actors. During the same period, I conducted a survey of one hundred car users, randomly selected when were they renewed their car licenses at the Department of Land and Transport in Bangkok. The survey (see Table 1) asked what modes of transportation they use, the costs, the amount of time it takes to commute, opinions on public transportation, and other related questions.

\footnotetext{
${ }^{3}$ Please see Appendix 1 for more information. Quotes from the interviews are in italics.
} 


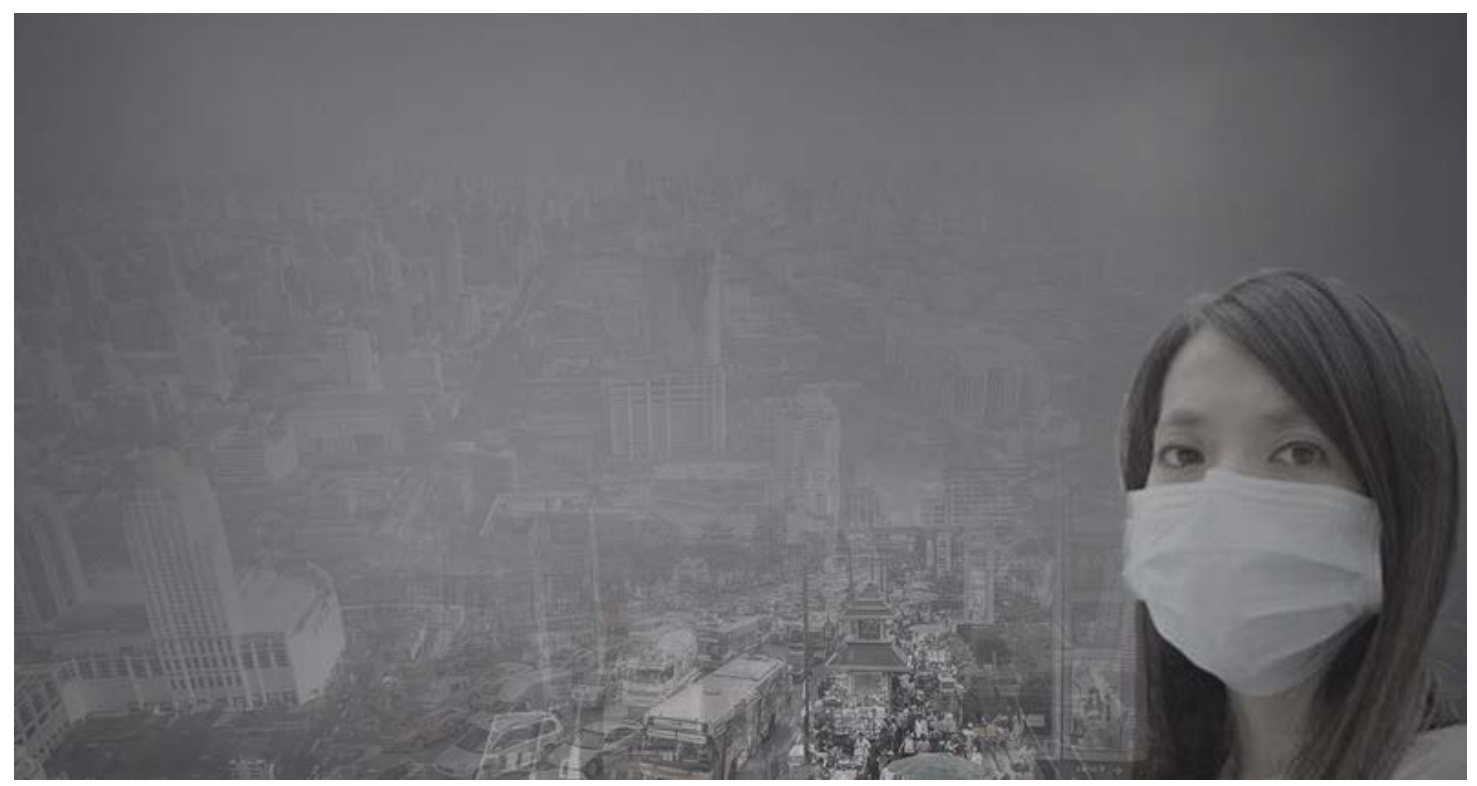

Figure 1: Bangkok's air pollution in October 2019. (source: The Nation 2019a)

I begin by describing the state's fragmented governance of the urban transport and the ways in which power relations underline these drivers and affect congestion. I then discuss the ways in which the city's historical development and materiality significantly contribute to congestion. I then describe the multiple political economic drivers behind the high degree of car usage and low degree of public transportation usage. I conclude with the implications of these findings.

\section{Fragmented, weak, and unequal governance of Bangkok's transportation system}

A number of interviewees asserted that fragmentation, policy incoherence, and differing priorities enervated governance of Bangkok's transportation. For example, they stated:

At the policy level, agencies don't have clear responsibilities. (\#20)

It seems to be problem of coordination. They don't have clear responsibilities between the national and local government level - mixing everything in Bangkok. (\#7)

The management has ... a very big problem. It's not just about many agents but also I use poor concepts of management. (\#2)

As these answers hint, an underlying driver of the city's poor governance of transportation is the limited power and fragmentation of the state institutions that govern the transportation system. Similar to Thailand's water and land sectors (see Marks 2019) and the country's overall administrative structure, the management of Bangkok's transportation is highly fragmented. This sector consists of numerous agencies at the central level each with its own interests. Each ministry and department operates as small kingdoms, each trying to control the issues and projects under its jurisdiction (Reynolds et al. 2012). This fragmentation has caused interagency clashes over budget allocations and control of projects in which scalar politics as well as policy incoherence recur. A fragmented centralized system which has disaggregated power and hindered policy coherence makes it difficult for government agencies at both the local and national level to effectively work together to provide services and govern their jurisdictions (Marks and Lebel 2016). 
The first problem is the differing responsibilities, legal authority, and incentives of the involved agencies. As Table 1 illustrates, there are a plethora of agencies-at least 12—whose actions affect transportation and congestion in Bangkok. The service regulations, such as the minimum number of vehicles, seats, and headways (the distance between vehicles system measured in time or space) are differently stated in each concession or contract signed with each operator.

\begin{tabular}{|c|c|c|}
\hline Agency & Under & Responsibilities \\
\hline $\begin{array}{l}\text { Bangkok Mass Transit } \\
\text { Authority (state-owned } \\
\text { enterprise [SOE]) }\end{array}$ & $\begin{array}{c}\text { Ministry of } \\
\text { Transport (MoT) }\end{array}$ & $\begin{array}{l}\text {-Provide bus services in Bangkok and vicinities } \\
\text {-Give licenses for private operators to operate buses } \\
\text { and oversee them }\end{array}$ \\
\hline $\begin{array}{l}\text { Bangkok Metropolitan } \\
\text { Administration (BMA) }\end{array}$ & BMA & $\begin{array}{l}\text {-Provide street and traffic signs and lights and set } \\
\text { parking spaces } \\
\text {-Builds and manages some streets (not inter- } \\
\text { provincial) } \\
\text {-Provides and manages bus stops }\end{array}$ \\
\hline Traffic police & Royal Thai Police & $\begin{array}{l}\text {-Manages traffic on the roads } \\
\text {-Enforces traffic laws }\end{array}$ \\
\hline Ministry of Finance & Ministry of Finance & -Controls/oversees budget for transportation projects \\
\hline Ministry of Highways & MoT & $\begin{array}{l}\text {-Builds and operates inter-provincial roads, some of } \\
\text { which run through Bangkok }\end{array}$ \\
\hline $\begin{array}{l}\text { Mass Rapid Transit } \\
\text { Authority of Thailand }\end{array}$ & MoT & -Oversees subway lines and BTS outside of Bangkok \\
\hline BTS Group Holdings & Private company & $\begin{array}{l}\text {-Operates the BTS within Bangkok and Bus Rapid } \\
\text { Transit (BRT) system }\end{array}$ \\
\hline $\begin{array}{l}\text { State Railway of Thailand } \\
\text { (SOE) }\end{array}$ & MoT & -Operates the train system and the airport link \\
\hline $\begin{array}{l}\text { Department of Land } \\
\text { Transport }\end{array}$ & MoT & $\begin{array}{l}\text {-Oversees regulation of bus system, including fares } \\
\text { and routes } \\
\text {-Gives out vehicle registrations and regulates } \\
\text { motorists who violate traffic laws }\end{array}$ \\
\hline $\begin{array}{l}\text { Office of Transport \& } \\
\text { Traffic Policy \& Planning }\end{array}$ & MoT & $\begin{array}{l}\text {-Formulating transport and traffic plans and policies } \\
\text {-Assesses performance of transportation system }\end{array}$ \\
\hline Family Transport & Private company & -Operates Saen Sap Canal boat service \\
\hline Chao Phraya Express Boat & Private company & -Operates Chao Phraya River boat services \\
\hline
\end{tabular}

Table 1: Agencies working on transportation in Bangkok and their responsibilities.

According to interviewees, the major actors are the MoT, BMA, and the police $(\# 5,10,15)$. Since all three are under different authorities and there is no lead agency, the first problem is that they do not have the incentive nor the authority to work together with others. As examples, BMA and BMTA cannot command the police to prioritize buses when the latter manages traffic. SRT expands the subway without ensuring that BMTA's bus routes are reformed so that they can 'feed' the new stations. Bangkok's roads are managed by different authorities, depending on whether they are classified as a highway. Further, since BMA has a limited mandate to be able to proceed with large transportation projects, it requires cooperation from many central-level agencies and grants beyond its normal annual budget from the central government. In years in which the BMA governor, who is elected, and the ruling party are from opposing parties, the national 
government has sometimes delayed these projects because it does not want the BMA governor's reputation to be enhanced from completing these projects, which would provide a boost to the governor's re-election prospects (\#2). Overall, as Table 2 shows, BMA has limited power over governing Bangkok's transportation.

To make matters worse, the number of agencies under the MoT rarely work together and have unclear responsibilities. For example, because it is unclear whether OTP or DLT is responsible for bus planning, they sometimes create differing bus reform plans. As another example, OTP is responsible for creating transport and traffic plans but its head is a level 10 in the Thai bureaucratic system, meaning he or she cannot order other heads around, such as the head of the powerful Department of Highways, who is a level 11 (\#10). Its limited authority diminishes the ability of OTP to implement the plans it creates.

As another example, the police give low priority to enforcing bus lanes and road space for buses when managing congestion. Police officers seek to reduce congestion in the area which they oversee. Specifically, they seek to reduce the overall number of vehicles in their area, rather than decrease the total number of users (\#10). Further, they "often think buses are a problem which makes traffic worse. They try to cancel bus stops" (\#16). The low priority they give to buses is evident not only in their lax enforcement of bus lanes but also the ways in which they manage overall traffic at intersections. Moreover, police do not have training in traffic management so some do not know to properly manage traffic lights and intersections (\#18; Wu and Pojani 2016). Subsequently, "in practice, police do everything related to traffic in Bangkok but have no knowledge" (ibid.). Another reason for the low priority police give to buses is that the police are a nationallevel agency and thus not under BMA nor the MoT and therefore do not have to obey the orders of these agencies. The police instead state that they prioritize the royal family and national leaders, using roadways to clear traffic for them (\#6). A transportation engineering professor believes that if the MoT or BMA managed traffic, the system would be better (\#19). But the police have thus far successfully resisted such changes.

The second related problem is that there is no lead agency managing transportation in Bangkok. The Transport for London agency oversees transport in London whereas the Transport for New South Wales manages transport in Sydney. The national government does not interfere with these cities' transportation governance. In contrast, in Bangkok there are a number of both national and local-level planning agencies, regulatory agencies, operators, the municipal government, and the police all involved, but with no lead metropolitan agency to ensure that these agencies work towards the same goal (\#10). A lead agency is needed to both formulate and then implement plans. Without one, fragmentation and inter-agency conflict ensues. A former Minister of Transport stated there have been some efforts to make the system fall under a singlecommand authority, but these efforts have been resisted because agencies do not want to give up their power (\#15). Without any regulatory mechanism in place to ensure that a plan will be realized, many projects are not implemented according to each plan. There is also no procedure in place to monitor and evaluate if plans are followed (Narupiti et al. 2014).

A third problem is that transportation is not deemed as part of urban planning. Numerous government agencies and politicians view traffic congestion to be caused by a lack of roads, not the manifestation of overall urban development (\#10). Further, the agencies responsible for planning are under a different department in BMA and a different ministry in the national government. Consequently, unlike in Japan where one ministry, the Ministry of Land, Transport and Infrastructure, works on land use and transportation together, in Bangkok there is limited cooperation between these agencies and subsequently, with little integration between urban land use planning and transportation (\#1).

A fourth problem is a frequent change in governments-there have been 13 different Prime Ministers and cabinets from 1991-2020. This has hindered policy coherence and implementation. As an example, the frequent change in governments has severely delayed bus procurement plans. A BMTA official stated:

During the last decade, BMA proposed to buy new buses. The first plan is to buy 6,000. But constant changes in government caused inconsistent and indecisive policies. When the government and minister changed, the last deal did not work so we had to all start over. This has happened many times since 2006. (\#14) 
As examples, in 2005, the Thaksin government proposed to rehabilitate BMTA by purchasing 3,500 new buses. However, the bidding was delayed due to the anti-Thaksin movement and, after the 2006 coup, the Surayud government scrapped the plan. In 2008, the Samak government approved a plan to procure 5,000 new buses but after he lost power, the new Abhisit government cancelled this plan (Kakizaki 2014).

A fifth barrier is that corruption remains rampant and widespread in Thailand. Its score in the Corruption Perception Index has backslid in recent year, coinciding with the military government's putsch in 2014. In September 2019, a United Nations Development Program asserted that the Thai government has lost up to lost 100 billion baht (US\$3.16 billion) due to corruption-related public procurement (Bangkok Post 2019a). A prominent example is from 2009: the Bhumjai Thai Party was implicated in a 64 Billion Baht (US\$2.02 billion) project to lease 4,000 new buses for use in Bangkok (Charoensin-o-larn 2010). ${ }^{4}$ The project was scrapped at result of these corruption allegations.

Besides being fragmented and sometimes corrupt, governance is unequal in terms of which groups' interests are represented. While policymakers do not want to ignore the urban poor, they seek to please middle class voters the most. For many years, politicians have kept bus prices low and sometimes free. However, they have done little other than this to help the urban poor, such as by improving the bus system, subsidizing the price of mass rail, or cracking down on illegal parking. One reason for this is that many bus users are not from Bangkok and are not registered, and have no right to vote in local elections (\#21). Thus, the needs of these users are not prioritized. Further, when the government does hold public hearings on bus reforms, the government holds them "like a protocol they need to do" but "does not really involve the poor" (\#7). Overall, politicians "do not care about buses" and bus riders have little political power so they "accept whatever is on offer" (\#10). But also they have limited economic power: they cannot afford to buy cars or to ride mass rail. Their low level of political and economic power means that "bus users' rights are not respected" and they must endure a "tough life" (\#21).

Instead, as a MoT consultant asserts, "the government provides the most support to private car of all modes of transportation" (\#32). Further, the government has invested heavily in the automobile industry and therefore encourages people to buy cars, embedding this value in Thai society. The middle class does not "request public transportation" (ibid.). According to a senior BMTA official, if the government enacts any policy, such as increased bus lanes or congestion pricing, they fear that "car drivers will mobilize and protest" (\#14). Further, many government officials are against congestion pricing since they work in areas which are the most congested and so they would have to pay the congestion fees (\#21). Nor are any "major political leaders pushing congestion pricing" (\#5). Interviewees feared that congestion pricing is unlikely to be implemented anytime soon $(\# 5,6,21)$.

Thus, overall, the governance of the transportation in Bangkok is weak and does not promote collaboration. The poor governance results in not only limited implementation of plans but also the limited ability to push through reforms. Instead, the incentive structure pushes bureaucrats to maintain the status quo. Another key reason for the lack of actions on congestion is the result of higher-level state processes, such as the frequent change in governments and suspension of the 2007 and 2014 Constitutions. Additionally, the unequal power structure of, and limited accountability within the system means that the interests of the middle class are given preference over those of the urban poor, who have limited voice. This results in the neglect of the bus system, expansion of private cars, and the continuation of heavy congestion. Another result is environmental injustice (Schlosberg 2007): the middle and upper classes are most responsible for Bangkok's emissions and air pollution but the urban poor bear the brunt of the impacts and have lower levels of mobility. Further, the urban poor have the least access to decision-making.

\footnotetext{
${ }^{4}$ The estimated cost of leasing and maintain one bus for 10 years was 7 million Baht (US\$221,323), but Bhumjai Thai's scheme charged 16 million Baht per unit (US\$505,881).
} 


\section{The uneven geography of transportation nodes and public transportation}

Bangkok's physical geography makes it inherently difficult to reduce congestion. This is due primarily to the widespread superblocks, limited roads, and the lack of transportation and land use planning. To understand how these obstacles developed, it is necessary to delve into the history of Bangkok's growth. Founded in 1782 by Rama I on the low-lying flood plain of the Chao Phraya Delta, Bangkok soon became the country's leading urban area. By 1820 it surpassed other urban settlements in Siam in terms of population and economic importance. During the initial era of the city's establishment (1782-1890), Bangkok was a water-based city, often referred by Westerners as the 'Venice of the East' (Sternstein 1982). Life revolved around an aquatic network of natural or dug canals which formed most transportation routes. Similarly, many residents lived in amphibious dwellings, either houses on stilts or floating houses (Thaitakoo and McGrath 2010).

In the 1890s, Bangkok began to change from a 'floating' water-oriented city to a land-based city. The first road, named the New Road, was opened in 1864 and was only nine kilometers long. Between 1890 and 1935, over 135 roads and 41 bridges were constructed. Shop houses and mansions replaced their aquatic counterparts. The government, an absolute monarchy at that time, allowed land ownership for the first time, which stimulated land-based settlements on either side of the canals. Population growth plus expanding trade and business caused the price of land to rise. This increase attracted the king and other elites to invest in private road construction and land speculation (Ouyyanont 1998).

In the decades after World War II, the city's land-based urbanization and population expanded rapidly. The city became the epicenter of the country's transformation from a local, agriculture-based economy to an internationalized, export-led manufacturing and service economy. The population boomed from one to over three million from 1950-1970. Rapid industrialization within and nearby Bangkok was a key driver of the city's urban expansion. However, the BMR not only grew rapidly, but did so in a haphazard and sprawling fashion. It grew outwards in a ribbon-like fashion along the three major transportation routes leading northward and eastward out of the urban core. These corridors became heavily congested while underutilized land remained between the corridors (see Figure 2) (Setchell 1995). This expansion of developments resulted in a situation in which all types of urban land uses, including individual houses, housing estates, and commercial and industrial buildings, were located beside each other. Development was "influenced as much by 'who owns land where' as by any sound urban planning principles" (Plumb 1999: 154). Thus, the city's laissez-faire expansion during these decades did not follow any form of land use planning. The 1992 metropolitan plan merely has an objective that it should "be used as a guide to the development of the city" (Bangkok Metropolitan Administration 1992).

Bangkok's unplanned urban expansion significantly affected the city's transportation geography in a number of ways. In order to build new narrow roads and housing estates around the city, developers adapted the ridges of rice fields, filled in many canals or reduced them to shallow drainage ditches and open sewers (Davivongs, Yokohari and Hara 2012). In the 1970s, the government ignored recommendations that canals should not be filled to accommodate vehicular traffic (Macan-Markar 2011). As of 2012, 78\% of canals which have been filled or covered were located in urban areas and the vast majority of these were those located on privately owned land (Davivongs, Yokohari and Hara 2012). Thus, many canals became narrow local roads (sois). Developers kept these roads narrow and limited because they preferred to develop a large chunk of land rather than smaller pieces. There was no law requiring developers to make these roads wider (\#1). Consequently, these sois became transportation bottlenecks, causing heavy congestion. Further, sois are so narrow that it is difficult for buses to traverse them (Daniere 1995).

Because the city expanded along major road corridors connected to very narrow sois, without any transportation or land use planning by either the national or local government, the city expanded without additional secondary roads, instead continuing with major and local roads. In comparison to the US, which has between $20-35 \%$ secondary roads in its cities, Bangkok has only $8 \%$ (\#1). The lack of secondary roads connecting the arteries means that the major roads consist of a mixture of inter-provincial and local traffic and consequently, the arteries become more congested. Moreover, because the city expanded with scant 
regulation or planning, it is difficult for mass transportation, particularly bus routes, to match its expansion (\#2).
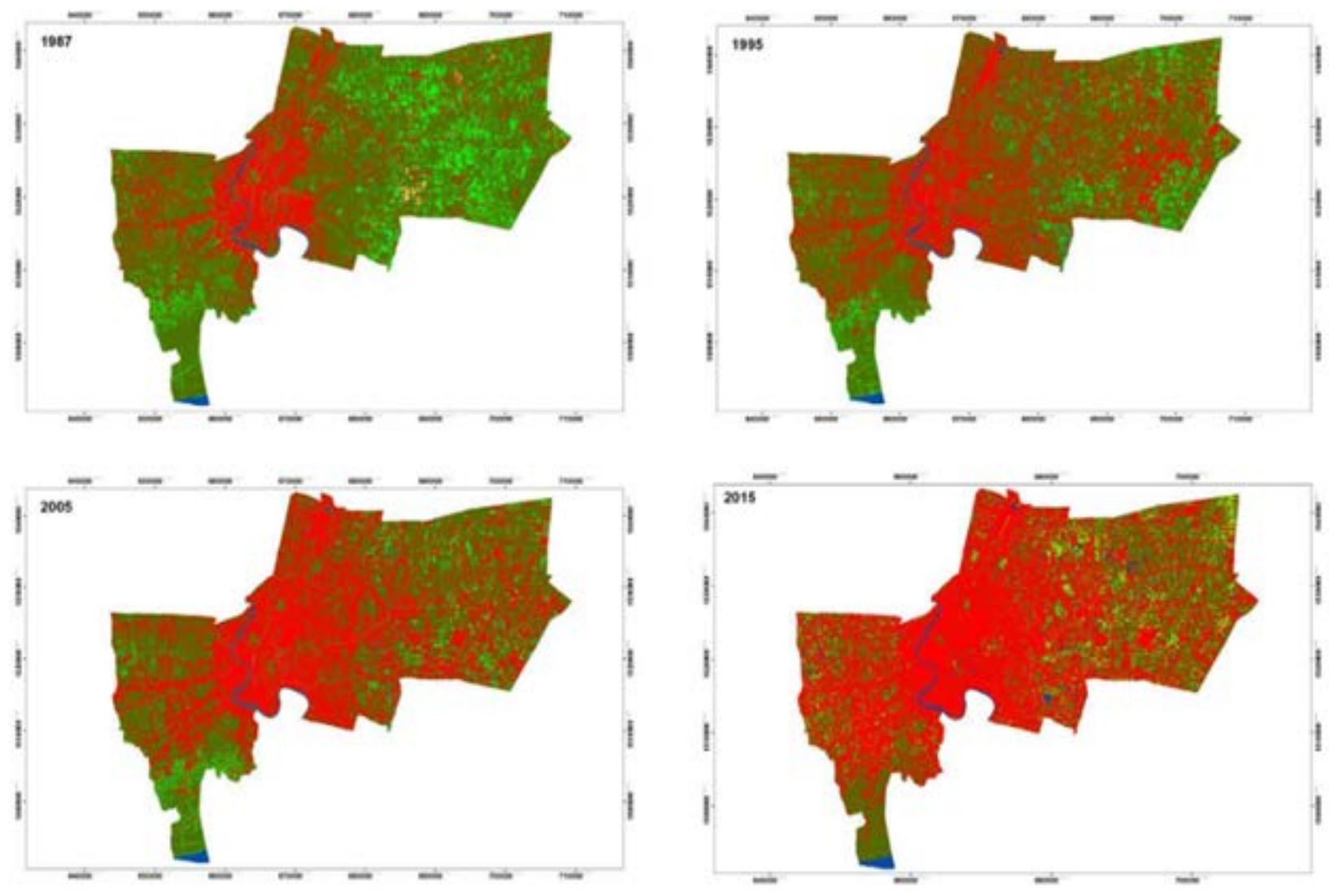

Figure 2: Growth of Bangkok's built-up area from 1987-2015. (source: Ali, Pumijumnong and Cui 2018)

Both the lack of urban planning and the city region's physical geography contributed to Bangkok's limited road space. According to UN-Habitat, if less than $30 \%$ of the land of a city is road space, the city will have congestion problems (Scruggs 2015). Whereas New York has a 38\% road-area ratio and Tokyo has 23\%, Bangkok has only 7.2\% (Phulsarikij 2018). This ratio became worse from the 2000s onwards, when urban areas of the adjacent provinces grew twice as fast as Bangkok did, but without sufficient roads being built (ibid.). Because the city expanded without sufficient public transportation expansion, the demand for cars rose rapidly. For example, from 1992-2002, the number of vehicles registered in Bangkok rose by $180 \%$ but the total road surface area rose by only approximately 10\% (Pujinda and Yupho 2017: 394). Bangkok's Skytrain system opened in 1999 but, as of 2020, it only covered 53.5 kilometers. In 2004, Bangkok's subway system started operating but it too only has covered limited parts of the city.

The city's low road-area ratio, in particular its dearth of secondary roads, has created 'superblocks' (Pujinda and Yupho 2017). Superblocks are large tracts of land without access to major roads and in the case of Bangkok, without public transportation. As Figure 3 illustrates, a person living in a house in Chok Chai 4 in northern Bangkok would have to traverse a long distance via local roads before he or she could access the main road or the closest subway station. As mentioned, it is difficult and unfeasible for buses to enter these local roads. Consequently, residents have to pay extra to use another form of transport (such as a taxi or motorbike taxi) or walk a long distance before they can access public transportation. This problem again 
arises once commuters take public transportation into the city and then want to travel to their workplaces. As a real estate developer stated: "This is the problem of the first and last mile. It is one of the main reasons why people don't use public transportation" (\#1). Further, few people walk long distances or ride bicycles. As a government consultant stated: because of these superblocks, it "is cheaper, faster, and more comfortable to drive" (\#3). The next section will also discuss additional reasons behind his statement.

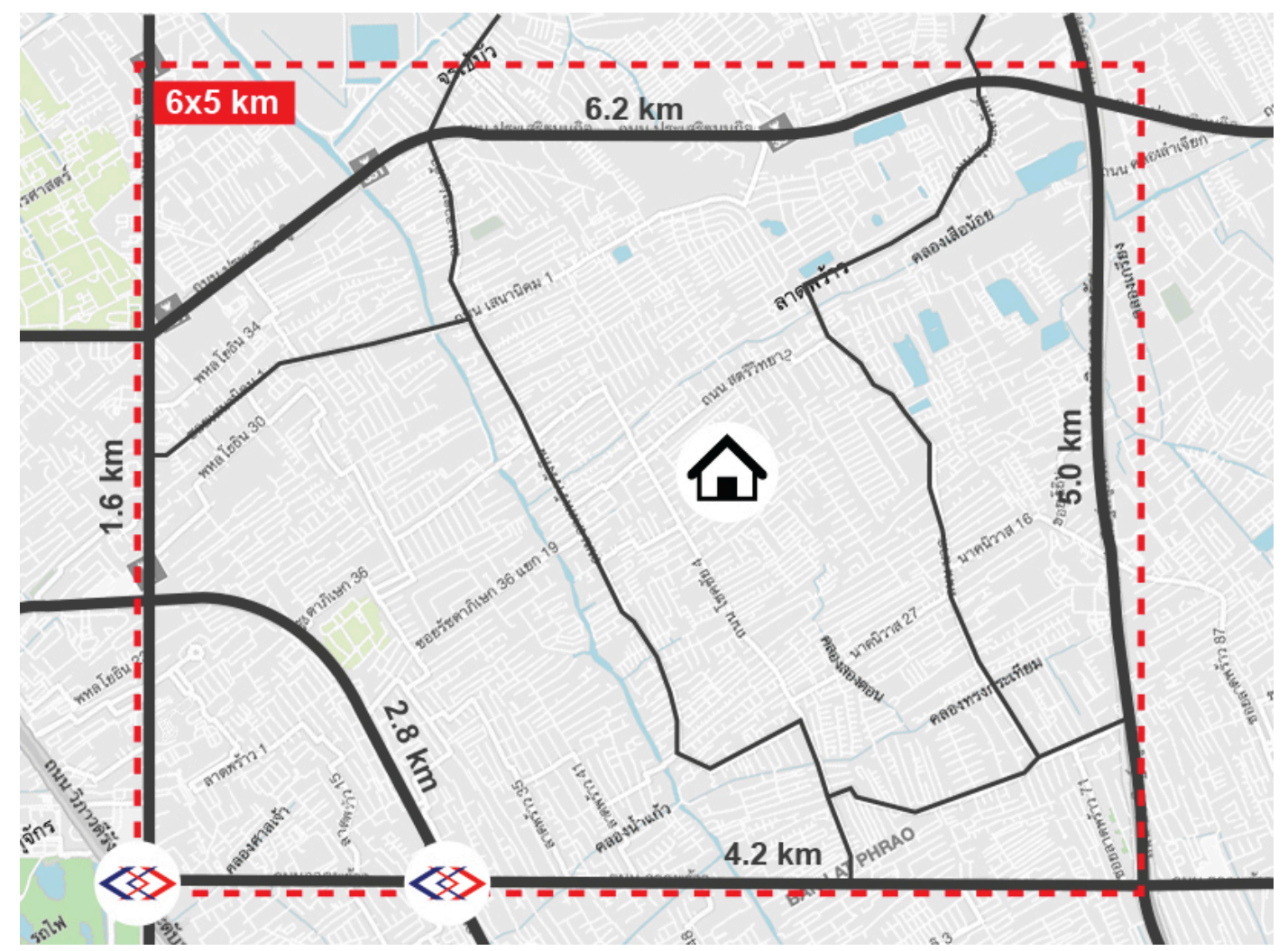

Figure 3: Example of a superblock in Bangkok. (Pujinda 2016)

When Bangkok's government, the Bangkok Metropolitan Administration (BMA), finally enacted land use plans, they did not alleviate congestion and instead exacerbated it. In the most recent comprehensive plan from 2013, BMA allowed extensive residential development in the suburbs, but forbade extensive commercial development (\#4 - see also Figure 4). The plan, the availability of cheaper land in the suburbs and the desire to have bigger residences facilitated the expansion of suburbs. The 2010 Population and Housing Census in Thailand indicated that nearly half of living quarters in Bangkok (45.7\%) were detached houses, which means a lot of Bangkokians resided in low-density residential areas (National Statistical Office Thailand 2012). However, many of these areas with detached houses lack public transportation. Since not only workplaces, but also the best primary and secondary schools and entertainment venues are concentrated in the inner city, many suburbanites decided to drive to the inner city (\#3). In particular, primary and secondary schools worsen congestion. Many middle- and upper-class parents forbid their children to take buses. Instead, they drive them to inner-city schools (\#10, 19). Overall, commuters now drive longer distances daily and the roads between these areas have become more congested.

Further, in recent years, the entire city has an increased number of shopping malls and condominiums (Marks and Zhang 2019). However, Bangkok's land use plans have never regulated the number of parking space in buildings. Instead, this is stipulated by the National Ministerial Order and the Local Ordinance issued pursuant to the Building Control Act of 1992. The requirement stipulates that each large building must 
have a minimum amount of parking slots based on its size (Chalermpong and Ratanawaraha 2020). ${ }^{5}$ This law is the opposite of that in many other countries, where condos are stipulated to have a maximum number of slots. Consequently, the construction of these new buildings, particularly the condominiums, led to additional cars inside the city and thus contributed to congestion (\#1, \#5).

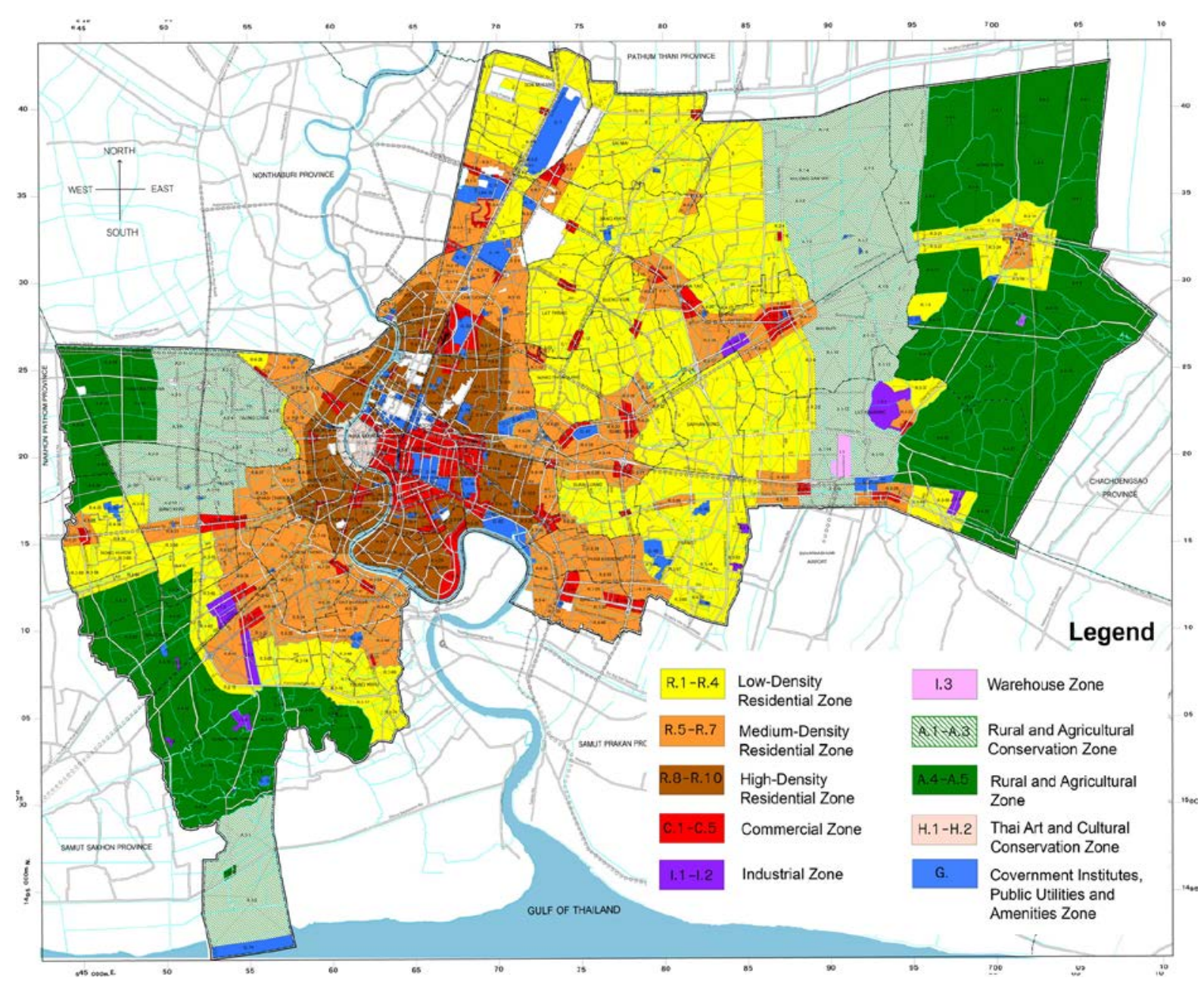

Figure 4: The 2013 Bangkok Comprehensive Plan. (Source: Bangkok Metropolitan Administration 2013)

Concurrently, since the 1980s when land prices skyrocketed in central areas, new low-income communities (LIC) have emerged in suburban areas, particularly near industrial areas in the east and north. From 1984-1994, housing within $10 \mathrm{~km}$ of the city center shrunk by about 20,000 units while LIC housing in the BMR increased overall by almost 70 percent (Daniere 1995). But neither the national nor local governments replaced LICs in the city's core with low-cost public housing. As a result, LIC dwellers were forced to move to new locations either on the outskirts of Bangkok or in the surrounding provinces of the

\footnotetext{
${ }^{5}$ The parking requirement depends on the type of land and building use, varying from 10 to $240 \mathrm{~m}^{2}$ of floor space per one parking slot. Large retail buildings have a steep requirement: one parking slot per $20 \mathrm{~m}^{2}$ of floor area. For example, Siam Paragon, one of the Bangkok's biggest shopping malls, has a retail space of almost 500,000 $\mathrm{m}^{2}$ and over 4,000 parking spaces (Chalermpong and Ratanawaraha 2020).
} 
BMR (Dowall 1992). The districts with the highest number of LICs are now located in the north and northeast of Bangkok (Marks 2015). Further, the population of LIC residents in the five BMR provinces has exceeded the population of those in Bangkok (Viratkapan and Perera 2006). However, since these peripheral areas have the least access to public transport, both buses and mass rail, it means that LIC residents suffer in terms of mobility.

In contrast, the rise of the local political elite who heavily profited from Bangkok's growth has had a strong influence on the city's haphazard form of urbanization and increased congestion. They have acted as brokers for outside investors wanting to buy a big piece of land, or invested in a number of housing projects. They consolidate land for these projects either through legal purchases or graft and intimidation, contributing to the rise of superblocks. Their excessive pursuit of property development, however, contributed to overbuilding in the BMR (Shatkin 2004). Additionally, local elected politicians in Bangkok and surrounding areas often have responded to the electorate's desire to adopt road-led development by giving higher priority to infrastructure development and income-generation projects over long-term planning (Askew 2004).

In sum, the city's largely unplanned and elite-led development has made congestion worse in a number of ways. First, it has led to a limited amount of road space, particularly that of secondary roads. This has subsequently led to the rise of superblocks. Further, the conversion of canals and rice field ridges into sois and built-up areas respectively has led to small and narrow local roads, which become traffic choke points. The proliferation of new condominiums and shopping malls without any parking restrictions upon them has led to an increased number of parking spaces and thus, cars. Finally, when the BMA has curbed development, such as by limiting the amount of commercial spaces in suburban areas and thus preventing any satellite cities from arising, this has also worsened traffic due to the concentration of office space, schools, and entertainment venues in the city center. Thus, the physical geography of the city already makes it difficult for state actors to reduce congestion in inner areas.

\section{Highest priority given to cars}

Bangkok's transportation system is clogged with private cars. The demand for this mode is higher than all other modes combined (see Figure 5) and is predicted to stay this way for at least the next decade (Jaensirisak et al. 2010). As of 2018, there were more than 4.3 million cars and 3.7 million motorbikes registered in Bangkok (Phulsarikij 2018).

This high demand for automobiles is due to the Bangkok's land use and transportation system pushing its users to purchase and then drive cars, if they can afford it. Despite drivers having to put up with long daily commutes and becoming stuck on the road, they persist in driving their cars for a number of reasons, a few which were mentioned in the previous section. Others, which will be discussed at length in the next section, are the severely underperforming bus system and the limited coverage and high costs of mass rail. The middle class, particularly those with children, prefer to drive.

Another reason is that the financial costs of purchasing and driving a car are relatively low. Pujinda and Yupho (2017) found that an average mass transit commuter pays approximately US\$120 per month whereas the average monthly cost of a private car is only US\$100. According to a government consultant, one reason the government keeps the price of cars low is that "a big player is the automotive industry" (\#3), the world's $12^{\text {th }}$ largest. The government has encouraged domestic consumption by making excise taxes lower than average. In contrast, Singapore's has a license fee and high excise duty tax which has caused car prices to soar above US\$80,000 (AFP 2017). In contrast, at Bangkok's motor expo in December 2018, the average car price was almost half: \$40,550 (Bangkok Post 2018). Further, Thailand has low annual registration fees, ranging from \$32 to \$224 per year. In comparison, Singapore car owners have to pay an annual road tax which is approximately ten times higher. A few years ago, when the Ministry of Transport (MoT) proposed to raise the annual registration fee, "people complained a lot. They spoke very loud" (\#7). Overall, in 2017, Thailand produced about 2 million vehicles, with 871,650 sold on the domestic market (Janssen 2018).

Moreover, the government has preferred to address congestion in the suburbs by building new roads, particularly new highways and expressways, without improving the feeder and secondary transit systems. This trend has led to further demand for cars. After their construction, real estate developers quickly 
developed land along these new roads into low-density, auto-dependent housing estates (Chalermpong 2018). Politicians and their cronies have often pushed for highways as a form of rent seeking, leading to accusations of land grabbing (Askew 2004).

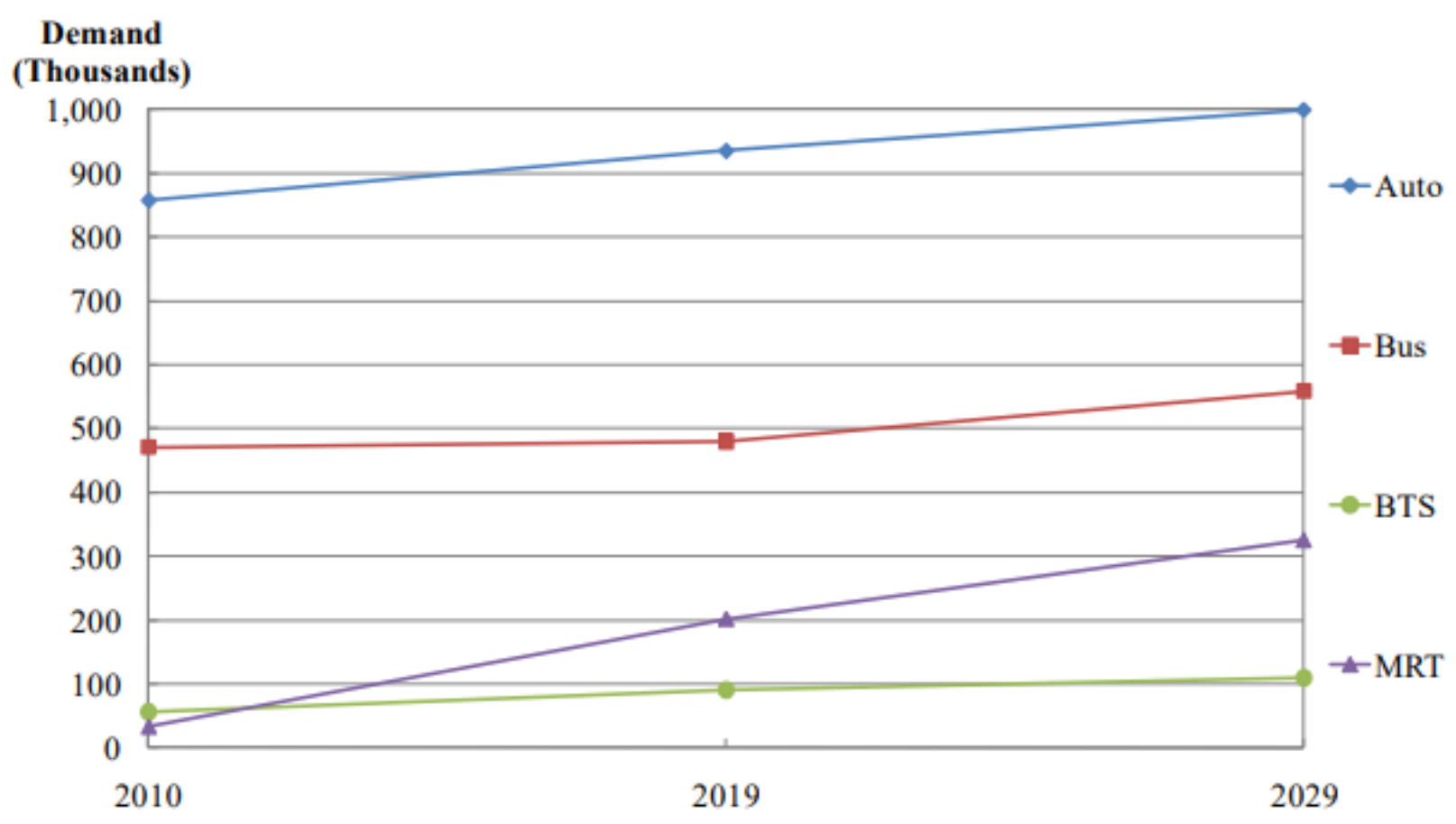

Figure 5: Demand of different transportation modes in 20102019 and 2029; MRT: mass rail transit (subway); and BTS: Bangkok Mass Train System (Skytrain). (Jaensirisak et al. 2010: 37)

Another incentive for Bangkokians to drive cars is the minimal costs of parking. This starkly contrasts to New York City, Sydney, and Hong Kong where the costs are very high (Siu 2017). Further, Bangkok's major shopping malls seek to attract car drivers by providing them free or low-cost parking. Commercial buildings also often provide employees free parking which encourages them to drive to work (\#7). Barter (2011) compared the amount of parking space required in commercial and retail spaces in major Asian cities and found that Bangkok was one of the two highest providers of space, the other being Kuala Lumpur (see Table 3). Similarly, he discovered that these two cities have the most generous residential parking standards. This is largely due to the stipulations in the aforementioned Building Control Act. It was passed in 1979 and has not been revised for four decades. New condominiums have been built close to mass rail stations so one might expect that they would have fewer cars. But in Bangkok, it is the opposite. Since these condominiums are expensive, wealthier people often live there and own more than one car (\#1).

Additionally, many drivers park on the side of the road, which disrupts traffic. This sometimes creates a clash between BMA who has designated areas where cars can park and the police. However, only the police, not BMA, have authority to fine those who park in illegal spots. BMA can suggest the police to take action, but the police has exclusive authority to act. According to a BMA officer, the police sometimes allow shop and restaurant customers to park illegally along busy streets in exchange for minor bribes from these venues' owners (\#8). This gives drivers an extra incentive to drive but also blocks traffic. 


\begin{tabular}{|l|c|c|c|c|}
\hline & $\begin{array}{l}\text { CBD Office } \\
\text { Building }\end{array}$ & $\begin{array}{l}\text { Non-Central Office } \\
\text { Building }\end{array}$ & $\begin{array}{l}\text { Shopping } \\
\text { Center }\end{array}$ & $\begin{array}{l}\text { Commercial } \\
\text { Requirements } \\
\text { Average }\end{array}$ \\
\hline Beijing & 0.5 & 0.5 & 0.3 & 0.35 \\
\hline Tokyo & 0.3 & 0.3 & 0.4 & 0.36 \\
\hline Singapore & 0.2 & 0.5 & 0.5 & 0.42 \\
\hline Hong Kong & 0.4 & 0.6 & 0.5 & 0.46 \\
\hline Dhaka & 0.5 & 0.5 & 0.5 & 0.50 \\
\hline Guangzhou & 0.6 & 0.6 & 0.6 & 0.60 \\
\hline Ahmedabad & 0.7 & 0.7 & 0.7 & 0.65 \\
\hline Taipei & 0.7 & 0.7 & 0.7 & 0.67 \\
\hline Seoul & 0.1 & 1.0 & 1.0 & 0.78 \\
\hline Hanoi & 1.0 & 1.0 & 1.0 & 1.00 \\
\hline Manila & 1.3 & 1.4 & 1.0 & 1.19 \\
\hline Jakarta & 1.0 & 1.0 & 1.7 & 1.33 \\
\hline Bangkok & 1.7 & 1.7 & 2.6 & 2.15 \\
\hline $\begin{array}{l}\text { Kuala } \\
\text { Lumpur }\end{array}$ & 1.5 & 2.6 & 2.7 & 2.40 \\
\hline Sydney & 0.0 & 3.3 & 4.0 & 2.83 \\
\hline
\end{tabular}

Table 3: Car parking required in office and retail buildings with Bangkok highlighted. Note: figures are per $100 \mathrm{~m}^{2}$ of gross floor space. (Barter 2011)

One disincentive for car owners to drive their cars is congestion pricing, which has been implemented in a number of cities, including London, Milan, and Singapore. However, in Bangkok no such pricing scheme exists. According to a senior official of Thailand Development Research Institute (TDRI), "the current government of Prayuth Chan-ocha has several priorities and congestion pricing is not one of them" (\#5). Such a policy would be unpopular because "Thai people are more afraid to pay than to suffer in traffic" (ibid.). A government consultant concurred: "There was too many protests against congestion pricing. Politicians don't want to lose popularity" (\#2). Results from the survey support their views: a majority (52\%) were against paying congestion pricing (Q8). In London, once the city initiated its pricing scheme, congestion was reduced and bus system became more effective and popular but also more people opted to use the city's well-run subway and train systems (Beevers and Carslaw 2005). In contrast, both national and local policymakers in Bangkok insisted that congestion pricing is not feasible until the mass rail's expansion is completed in the next 5-10 years (\#2, 9). However, a study found that the mass rail expansion will unlikely reduce congestion significantly unless congestion pricing is also implemented (Jaensirisak et al. 2010). A senior TDRI official agreed:

Cars will fill the extra space [from metro users]. If I don't have a pricing mechanism to force cars out of congested areas ... nothing will change. (\#5)

Finally, societal pressure and cultural values also impel Bangkokians to buy and drive cars. This can be seen in car advertisements on YouTube, television, and in magazines. In these ads, cars are culturally prestigious and status symbols. As a Prachathai reporter told me: 
Most Thais in their 20s have the goal of buying a new car. It is a step of life ... Most don't think about the environmental impact, they just think about convenience. (\#10)

An international environmental think tank official who lives in Bangkok narrated a representative story about his neighbor, a vice-president of a leading financial institute. Instead of walking a few minutes to the Skytrain and riding it to work, she drives her luxurious car, often becoming stuck in traffic and spending more time, sometimes more than double, than if she had taken the Skytrain. When asked why she made this decision, she replied: "I'm the Vice President. It would not look good if I did not come to work in my car" (\#11). The findings of a study of high-income condominium residents living along the Sukhumvit line of the sky train reflect her decision: they too preferred to commute by car rather than ride the Skytrain (Pujinda and Yupho 2017). According to a BMA officer, a consequence of this cultural bias towards cars is, that "the government has facilitated roads for using cars" (\#8).

Overall, as a Voice TV host asserted, "the system pressures you to buy a car" (\#12). That is, a combination of political, economic, and cultural drivers push Bangkokians to buy cars_-as long as they can afford it. The high number of cars combined with limited road space obviously translates into high levels of congestion. However, drivers are "used to being stuck on the road" (\#10) and "put up with bad traffic" (\#13). Survey results reveal that drivers spend a lot of time in traffic: $84 \%$ spend more than an hour per day driving and 57\% spend over two hours per day (Q1 in Table 1). They would, however, rather be stuck in traffic in a car than on a bus (\#12) and they are not willing to pay congestion prices (\#5, Q8 of Table 1). Consequently, as seen in China (Zhang 2019), pressure from the middle and upper classes to change the inefficient system is not forthcoming. However, for those who cannot afford a car, the bus remains a popular option, but, as the next section shows, they suffer because the bus system is riddled with shortcomings.

\begin{tabular}{|c|c|c|}
\hline Questions & \multicolumn{2}{|c|}{ Answers from 100 survey questionnaires } \\
\hline $\begin{array}{l}\text { 1. How much time do } \\
\text { you spend driving per } \\
\text { day? Is that time too } \\
\text { much? }\end{array}$ & $\begin{array}{l}\text { 1. }<1 \text { hour }-16 \% \\
\text { 2. } 1-2 \text { hours }-27 \% \\
\text { 3. } 2-3 \text { hours }-25 \% \\
\text { 4. } 3-4 \text { hours }-23 \% \\
\text { 5. }>4 \text { hours }-9 \%\end{array}$ & $\begin{array}{l}\text { 1. Too much }-75 \% \\
\text { 2. Moderate }-16 \% \\
\text { 3. Not too much }-9 \%\end{array}$ \\
\hline $\begin{array}{l}\text { 2. Studies show that } \\
\text { Bangkok has some of the } \\
\text { world's worst traffic. } \\
\text { Who do you blame for } \\
\text { it? }\end{array}$ & \multicolumn{2}{|c|}{$\begin{array}{l}\text { 1. Everyone }-10 \% \\
\text { 2. Myself }-11 \% \\
\text { 3. Prime Minister \& relevant government actors, including police }-37 \% \\
\text { 4. Bangkok city planner and transportation system - } 11 \% \\
\text { 5. Undisciplined motorists }-14 \% \\
\text { 6. All motorists }-11 \% \\
\text { 7. No one }-6 \%\end{array}$} \\
\hline $\begin{array}{l}\text { 3. Do you ever take the } \\
\text { bus? If so how often? }\end{array}$ & $\begin{array}{l}\text { 1. Yes, I do }-80 \% \\
\text { 2. No, I don't }-11 \% \\
\text { 3. No, but I used to before having } \\
\text { my own car }-9 \%\end{array}$ & $\begin{array}{l}\text { 1. Often (weekly) - } 18 \% \\
\text { 2. Normal (a monthly) - } 19 \% \\
\text { 3. Not often (every } 3 \text { months) - } 21 \% \\
\text { 4. rarely (every year) - } 22 \% \\
\text { 5. never - } 22 \%\end{array}$ \\
\hline
\end{tabular}




\begin{tabular}{|c|c|c|}
\hline $\begin{array}{l}\text { 4. If you do not take it, } \\
\text { why? }\end{array}$ & \multicolumn{2}{|c|}{$\begin{array}{l}\text { 1. Driving is more convenient, safer, and it saves time }-46 \% \\
\text { 2. Uncertain and unpunctual time travel, as well as being packed and slow - } \\
21 \% \\
\text { 3. Bad service and not safe }-4 \% \\
\text { 4. Both } 2 \text { and } 3-9 \% \\
\text { 5. The limit of transit and bus service }-3 \% \\
\text { 6. Lack of bus routes throughout Bangkok and its suburb }-9 \% \\
\text { 7. Other }-6 \%\end{array}$} \\
\hline $\begin{array}{l}\text { 5. What would you rate } \\
\text { the bus system from } 1 \text { to } \\
10 \text { (10 being the best) }\end{array}$ & \multicolumn{2}{|l|}{$\begin{array}{l}\text { 1. } 1-3-48 \% \\
\text { 2. } 4-5-39 \% \\
\text { 3. } 6-7-14 \% \\
\text { 4. } 8-10-6 \%\end{array}$} \\
\hline $\begin{array}{l}\text { 6. What changes are } \\
\text { needed for you to take } \\
\text { the bus more? }\end{array}$ & \multicolumn{2}{|c|}{$\begin{array}{l}\text { 1. Deficiency of bus network system }-16 \% \\
\text { 2. Inconvenience }-7 \% \\
\text { 3. Low quality of services }-26 \% \\
\text { 4. Infrequency and uncertain bus timetable (punctuality) }-21 \% \\
\text { 5. Others (railways or bus lanes) }-6 \% \\
6 \text {. Responses } 1 \text { and } 4-24 \%\end{array}$} \\
\hline $\begin{array}{l}\text { 7. What is your top } \\
\text { suggestion to improve } \\
\text { Bangkok's traffic? }\end{array}$ & \multicolumn{2}{|c|}{$\begin{array}{l}\text { 1. The overall mass transportation system improvement (networking all public } \\
\text { transport nodes) - } 29 \% \\
\text { 2. Improve bus coverage and better feed mass rail stations }-8 \% \\
\text { 3. Limit number of cars, driving licenses and stricter enforcement of traffic laws, } \\
\text { and congestion tax }-35 \% \\
\text { 4. Better traffic management (e.g., training police about traffic control) }-10 \% \\
\text { 5. Construct bus lanes }-6 \% \\
\text { 6. Encourage drivers to be more disciplined and aware }-6 \% \\
\text { 7. Other - } 6 \%\end{array}$} \\
\hline $\begin{array}{l}\text { 8. Would you be willing } \\
\text { to pay a driving "tax" in } \\
\text { order to improve } \\
\text { Bangkok's traffic? }\end{array}$ & \multicolumn{2}{|l|}{$\begin{array}{l}\text { 1. Yes }-48 \% \\
\text { 2. No }-52 \%\end{array}$} \\
\hline $\begin{array}{l}\text { 9. Do you care about the } \\
\text { environment? If so, does } \\
\text { this affect how much you } \\
\text { drive? }\end{array}$ & $\begin{array}{l}\text { 1. Yes }-95 \% \\
\text { 2. No }-5 \%\end{array}$ & $\begin{array}{ll}\text { 1. A lot }-20 \% & \text { 4. Less }-6 \% \\
\text { 2. More }-36 \% & \text { 5. Least }-5 \% \\
\text { 3. Moderate }-33 \% & \end{array}$ \\
\hline $\begin{array}{l}\text { 10. What is your family's } \\
\text { monthly income } \\
\text { approximately (in } 000 \\
\text { Baht)? } \\
\text { Note: US } \$ 1=31.2 \text { Baht }\end{array}$ & \multicolumn{2}{|l|}{$\begin{array}{l}\text { 1. }<30(<\mathrm{US} \$ 960)-4 \% \\
\text { 2. } 30-50(\mathrm{US} \$ 960-1,600)-16 \% \\
\text { 3. } 50-70(\mathrm{US} \$ 1,600-2,240)-15 \% \\
\text { 4. } 70-100(\mathrm{US} \$ 2,240-3,210)-17 \% \\
\text { 5. } 100-200(\mathrm{US} \$ 3,210-6,420)-21 \% \\
\text { 6. } 200-300(\mathrm{US} \$ 6,420-9,630)-9 \% \\
\text { 7. }>300(>\mathrm{US} \$ 9,630)-14 \% \\
\text { 8. Unrevealed }-4 \%\end{array}$} \\
\hline
\end{tabular}

Table 2: Results from random survey of 100 car owners, 2018. 


\section{Bangkok's severely underperforming bus system}

An obvious solution to the problem of too many automobiles in Bangkok is persuading drivers to shift to using public transportation, especially public buses. Compared to mass rail and boats, buses have higher flexibility, lower production and operational costs, and thus could better connect Bangkok's suburbanites to the inner city (Thongphat and Arporniem 2017). However, for a number of reasons, this has not happened. In recent years, public buses instead have been hemorrhaging passengers: dropping from over 4 million passengers per day in 1992 to only 1.2 million per day in 2019 (The Nation 2019b). The organization responsible for providing bus services, the Bangkok Metropolitan Transportation Administration (BMTA), is heavily in debt and runs at a loss. Passengers are unhappy with wait times and insufficient information given at bus stops (Thongphat and Arporniem 2017). This section discusses the underlying structural drivers behind the poor performance of the bus system.

The first problem undermining the bus system is that the buses are outdated and of poor quality. They "physically look bad and polluted" (\#16). Most of the buses have been running for over 30 years. BMTA has bought only a handful of new buses since then (Kakizaki 2014). Interviewees unanimously considered the buses old and outdated and said they frequently break down (\#10,12,14,15). The overall poor quality of the bus system acts as a deterrent for the middle class to use buses $(\# 10,14)$. Survey results_also back up this argument: only $18 \%$ use the bus at least once per week (Q3) and the low quality and deficiencies in services were two of the three main reasons why they did not take the bus more often (Q6). According to a TDRI senior official: "if BMTA buys new buses regularly, their problems would be solved quickly" (\#6).

There are two major reasons why Bangkok's buses are outdated and of such poor quality. One reason, as already mentioned, is the frequent change in government. The other, according to a BMTA senior official, due to its high level of debt, his organization cannot purchase buses without support from higher levels of government due to their high level of debt. However, BMTA has operated at a loss for the last few years.

A second weakness is that the bus routes as are outdated as the buses themselves and, after the city expanded, routes no longer meet Bangkok residents' transportation needs. The current bus routes have not been changed in over three decades while both land use and mass rail options have altered significantly. Consequently, buses do not serve as feeders to mass rail stations. Instead, many bus routes overlap, with some sharing the same routes for up to 40 kilometers (Luathep et al. 2017). Legally, BMTA cannot expand or change its routes without permission from the Department of Land and Transport. However, according to a BMTA senior official, it takes DLT seven years to complete this process (\#14). The lack of bus coverage in suburban areas, such as Pathum Thani and Nonthaburi, is particularly problematic and is one motivating factor behind residents in these places to purchase cars (Luathep et al. 2017).

A network of bus lanes would significantly improve the buses' efficiency and reliability, as seen globally in many cities. A Bangkok architect asserted that a bus route he used took two hours during rush hour but 20 minutes at night. Added bus lanes would have similar effects (\#18). However, only a few areas of Bangkok have bus lanes (\#17). The existing lane network is scattered and unconnected, rendering those lanes less effective (Kijmanawat and Karoonkornsakul 2016). The limited number of bus lanes is due to limited road space (\#3), the current road system of sois intersecting with main roads_-bus lanes would block traffic from the sois (\#12) —and widespread objections from the middle classes. They protested against the bus lane built in 2010 for the Bus Rapid Transit (BRT) system (\#1). Further, signs and markings in most lanes are unclear, such as where they begin and end, and which vehicle types are allowed in them. The lack of signage and communication makes it harder for drivers to follow bus lane rules (ibid.).

Internal weaknesses within BMTA have further damaged governance of Bangkok's bus system. The biggest problem, as mentioned, is that BMTA is in heavily in debt. This debt began at the agency's inception which made it difficult for it to improve its service (see Kakizaki 2014). BMTA did make a profit in the 1990s, but that was an exception and since it has been operating at an annual loss. In 2017, their net loss was 4.9 million Baht (US\$157,150), and similar sums have been incurred annually since 2010 (Bangkok Mass Transit Authority 2018). The reasons for its operating losses are numerous. First are high operating costs, including a large number of employees and their high salaries, fuel costs, and maintenance fees. Without an automated fare collection system, each bus needs two workers: a driver and a fare collector. Therefore, 
personnel costs double. Second, the fares are too low and do not incorporate the real cost of providing services. The fare has been fixed based on more than a decade-old value of money and services. Recently, fare prices were raised, but only to half of their real costs (BMTA 2019). The constraint here is political: fares are the responsibility of the DLT, not the BTMA. Politicians have pushed DLT to keep prices low. They want to receive votes from the urban poor, the main bus users, and this group complains when prices are raised (\#15). Third is that a reduced number of passengers equates to reduced revenue. Being heavily in debt means that it is difficult for BMTA to improve its service by expanding and improving its fleet and the technology it uses.

BMTA has a monopoly to issue licenses to numerous private operators to operate additional bus services, and it does so because of its own limited capacity. About 56\% of the buses in Bangkok are privately operated. ${ }^{6}$ However, the regulatory framework has created a conflict of interest because BMTA plays the roles of both operator and regulator. Due to its poor governance and limited resources, the agency has not been able to ensure a high level of service quality among private operators (Thongphat and Arporniem 2017). This has led to dissatisfaction and a reduced number of passengers on privately-operated buses.

Buses are stigmatized by the middle class, as mentioned above. They view buses as "invading upon their car lanes" and oppose improvements in bus services because it is their "taxpayer money." On Thai messages boards, drivers often complain that buses encroach upon car lanes (\#18). Drivers think that buses are "the root of the problem" and "want to remove buses." The middle class perceives buses as something that makes "life difficult" (\#10). A Prachathai reporter asserted that this thinking comes from the attitude among many Thais that since the bus fare is inexpensive, the system is of poor quality and thus only for lowincome people (ibid.). My survey results confirm that the wealthiest respondents use the bus the least. Consequently, the middle class has not pushed to improve the system.

A positive development is that three civil society organizations are pushing to improve the bus system's services and quality: I Love Thai Bus, Bangkok Bus Club, and May Day. For example, May Day has renovated a number of bus stops in Bangkok so that users have a better knowledge of the bus routes (\#17). However, according to a leading activist, without addressing the root causes of the problems with the network, these groups are merely making small changes to persuade people to use the bus more. They have limited power to successfully push for major changes. Further, there is no wider social movement pressuring BMTA and other government agencies to improve the bus system. Users complain but do not collectively push for change (\#21). This is understandable given bus users' limited economic and political power but also the extensive amount of time they spend daily riding the bus.

Overall, a number of political, economic, and cultural factors weaken Bangkok's bus system. They include the populist sentiment of politicians, BMTA's poor governance structure and heavy debt, the low quality of buses, outdated routes, the police's low priority of the bus system, and middle class stigmatization of buses. Together, these factors contribute to the low and declining ridership of buses as well as its poor performance. However, the urban poor cannot afford cars so they must continue to rely upon taking the bus, unless they purchase motorbikes, sometimes through loans. Consequently, with limited purchasing power, they unfairly suffer the most from the poor bus system: a lack of justice in the social relations of mobility in the city (Lefebvre 1991).

\section{Lack of alternative public transportation modes}

Given the poor performance of the bus system, many Bangkok residents prefer not to use it. The only two alternatives to using private vehicles, such as cars or motorbikes, are public boats and mass rail (cycling, given air pollution, heat and road dangers, has a very low modal share). However, less than 100,000 people ride the public boats daily: 60,000 for the Saen Sap canal and 30,000 on the Chao Phraya Express Boat (Jotikasthira and Bangprapa 2018). Overall, boat transport is only 12\% of total public transport. In 2016, Prayuth suggested reviving boat transportation in a network of Bangkok canals. In 2018, BMA suggested

${ }^{6}$ As of 2017, BMTA operated 2,671 buses while private operators managed 3,444 buses (Bangkok Mass Transit Authority 2018). 
developing five canals to be used for boat shuttling (ibid.), but, as of 2020, nothing has been developed and even if these plans materialized, the number of total boat users would still be limited. This is because boat transport has geographical limitations in terms of potential access, and rivers and canals are used for multiple purposes. There are only three major water transport routes: Chao Phraya River, and San Saeb and Phasee Chareon canals, which cannot cover all areas of the city. Moreover, during the rainy season (four months long), when water flows are strong and the water level is high, some routes must stop running.

In theory, the relatively new mass rail could significantly reduce the city's congestion. Bangkokians "support mass rail because it does not use the roads" (\#6). A senior TDRI official concurred: "there is no other policy to get people out of their cars" (\#5). However, many current hurdles prevent private vehicle drivers from switching to mass rail. The first is the system's limited coverage. Given the incessant heat and low walkability within Bangkok (Sabpaitoon 2018), residents prefer door-to-door commuting (Pujinda and Yupho 2017). Huge pockets exist within the city where mass rail does not reach. Bangkok is currently decades behind where it should be in building an integrated mass rail network. Combined, the Bangkok Mass Transit System, Metropolitan Rapid Transit and Airport Rail Link networks only cover $110 \mathrm{~km}$, compared to $178 \mathrm{~km}$ in much smaller Singapore (Wancharoen 2019). The reasons behind the limited network include constant changes in government (six from 2006-2019) which has resulted in a lack of continuity even though there has been bipartisan political support for the 12-line Mass Transit Master Plan (M-MAP); poor coordination between agencies responsible for Bangkok's public transportation; and the lack of an integrated transport planning framework, which has often been subjected to political interference. Implementing the MMAP has always been plagued by delays either at the approval, contracting or construction phase (Marks and Brown 2014).

Another problem is inequality within the mass rail system. Since land prices are higher near stations, only the upper middle class and wealthy can generally afford to live there. A MoT consultant estimates that only "10\% can access the stations" (\#6). Moreover, the ticket prices for mass rail in Bangkok are the highest in Southeast Asia, causing a significant financial burden for commuters. The average ticket price is $20 \%$ higher than in much-wealthier Singapore. The fare per kilometer (US\$0.48) is higher than the London rail system, which is US\$0.40, and is triple that of Hong Kong at US\$0.16 (Bangkok Post 2019b). A study by TDRI found that the urban poor can only afford to pay up to 11.7 baht (US\$0.38) per trip, much less than the Skytrain's or subway's starting price of 16 baht (US\$0.51) (Hongtong 2019). Consequently, they cannot afford to take mass rail and must rely upon the bus system or personal motorcycles.

More positively, the government is significantly expanding the mass rail system, with a further 340 $\mathrm{km}$ and 196 stations expected to be completed by 2025 (Wancharoen 2019). Some government officials believe that the expansion will reduce congestion (\#2, 9). However, a senior TDRI official predicts that even after the expansion is complete, without congestion pricing, "congestion will not be reduced" in many areas because the extra space on roads will be "filled with new cars" (\#5) and there is "no mechanism to force cars out of congested areas." A MoT consultant conducted a study which confirmed this opinion: it predicted that traffic would worsen by 2.9\% from 2014-2029 (\#2). Mass rail expansion is supported by the middle class who do not need to sacrifice road space and particularly by the elite who benefit from increased land prices near stations.

Overall, alternatives modes of public transportation-mass rail and public boats—are too limited to significantly reduce congestion. Moreover, the mass rail system further heightens inequality due to high ticket fares and the poor's limited access to the stations. Therefore, they must continue to rely on the poorly performing bus system or private transportation.

\section{Conclusion}

Using a UPE framework reveals that Bangkok's traffic congestion and high level of carbon emissions from transport is the result of numerous political-economic and cultural variables, but also the city's built environment. Its urban development, including the lack of secondary roads, the small width of tertiary roads, proliferation of superblocks, and a lack of integration between land use and transportation planning, makes it inherently difficult for planners and bureaucrats to reduce congestion. Concurrently, automobile-dominant 
transport planning has become embedded in the city's transport policies, such as its parking regulations, annual registration fees, and lack of congestion pricing. State actors also give the lowest priority to the bus system in the ways they have implemented or under-enforce existing policies. Police rarely fine those parking illegally or enforce bus lanes, give highest priority to cars when directing traffic, and there is institutional neglect of policies that could help the bus system, such as increasing bus lanes and implementing congestion fees. These factors push residents to purchase and drive cars, and also help explain why a high level of congestion has developed and persists.

Urban transport in Bangkok is highly unequal and unjust in terms of its carbon emissions, and mobility. As I have argued they are forced, rather than choose, to rely upon underperforming buses or motorbikes and they suffer the most in terms of exposure to roadside pollution. They are also forced to live in peripheral areas which have the least access to public transport. Further, in a society heavily divided along class lines (Marks, Connell and Ferrara 2020), higher earners and the upper classes perpetuate the system, buying into the capitalist commodification of automobiles as must-have objects. Environment issues are a low concern for most of them, and there are few incentives or regulations to make them more of a concern (Marks 2011). The Thai state does not want to offend the middle class and the wealthy because it relies on their support, and many leaders are comprised of people from these classes (Farrelly 2013). The irony, however, as Beck (1992) argues, is that the effects of climate change, such as floods and heat waves, and urban air pollution affect all classes, including the wealthy. While they can buy expensive masks, air purifiers and cars, they still cannot escape from Bangkok's poor air quality or awful congestion.

Concurrently, fragmented governance, frequent changes in leadership, electoral pressure, and systematic inertia severely hinder state actors from being able to address congestion. There are conflicts and tensions between which agencies should do what in terms of urban transport governance, and over undertaking other measures that affect road traffic. Also, the lack of coordination between agencies working on urban transport also weaken their capacity to improve the sector. Overall, incomplete decentralization, due to the retention of power and resources by central bureaucrats, alongside horizontal fragmentation has undermined efforts (also see Marks and Lebel 2016).

An UPE analysis of Bangkok's traffic congestion also provides insights into the ways poor governance, misaligned incentive structures, and insufficient urban planning cause congestion-a public bad-to persist as well as contributing to the city's 'splintered urbanism' (Graham and Marvin 2001). The configuration of public and private vehicles, infrastructure and urban space unjustly fragments the urban experience, creating different cities and emissions and air pollution levels for different groups, as well as linking certain spaces while partitioning others. However, due to the limited power of the urban poor, solutions to congestion, such as expanding mass rail without congestion pricing, are post-political (Swyngedouw 2010)_meaning that the formation of autocratic and technocratic regimes of urban politics have excluded the citizenry, particularly marginalized groups, from making decisions about urban transport (also see Koglin and Rye 2014). Instead, regimes and policy making are shaped by elite interests. Consequently, addressing power imbalances between classes is needed.

From a policy perspective, what can be done to reduce congestion and make the sector more equitable? BMA could:

1. Follow Japan's lead and use land readjustment projects to widen small roads and increase road connectivity, thereby reducing the size and number of superblocks (See Francisco De Souza, Ochi and Hosono 2018).

2. Persuade parliament to revise the Building Control Act so that a maximum number of parking slots is set in future buildings, and work with the police to crack down on illegal parking and find ways to make it more expensive.

3. With support from MoT, invest heavily in improving the bus system to make it more attractive to potential users. This would include buying a new fleet of buses, rerouting buses to better meet user demands and feed mass rail stations, improving bus stops, and 
expanding the numbers of bus lanes. BMA could also work with the police to better prevent cars from using bus lanes.

4. Implement congestion pricing in Bangkok's inner areas, a scheme which has proven successful in London, Singapore, and elsewhere.

5. Revitalize canals and expand the number of public canal boats and routes, particularly for low-income communities, to better provide another alternative mode of public transportation, which is cheap and quick.

6. Improve walkability by improving sidewalks and crossings and providing more green space. Making the city more walkable would reduce the demand for driving.

While implementing these suggestions will be difficult, given bureaucratic fragmentation, institutional inertia, budgetary constraints, and criticism from swathes of the public and vested interests, it would lower Bangkok's place in congestion rankings, reduce emissions, improve air quality, and make Bangkok more equitable and livable.

\section{References}

AFP. 2017. Electric car-sharing is Singapore's latest measure to fight traffic. France 24. December 12. https://www.france24.com/en/20171212-singapore-launches-electric-car-sharing-service [accessed: June 18 2019].

Ali, G., N. Pumijumnong and S. Cui. 2018. Valuation and validation of carbon sources and sinks through land cover/use change analysis: the case of Bangkok Metropolitan Area. Land Use Policy 70: 471478.

Askew, M. 2004. Bangkok: place, practice and representation. London: Routledge.

Bae, C.-H. C. and Y. Suthiranart. 2003. Policy options towards a sustainable urban transportation strategy for Bangkok. International Development Planning Review 25(1): 31-51.

Bangkok Mass Transit Authority. 2018. Annual Report 2017. http://www.bmta.co.th/sites/default/files/files/download/annualreport2560-compressed.pdf [accessed: June 20 2019].

Bangkok Metropolitan Administration. 1992. Comprehensive plan for the Bangkok Metropolis. Bangkok: BMA.

Bangkok Metropolitan Administration. 2013. Executive summary: 20-year development plan for Bangkok Metropolis, $\quad$ Phase $\quad 1$ : $2013 \quad-\quad 2017 . \quad$ Bangkok: http://www.bangkok.go.th/main/backoffice/upload_editor/file/summary_20y_phase1.pdf

Bangkok Post. 2018. Motor Expo bookings up 10\%, orders worth B56bn. Bangkok Post December 11. https://www.bangkokpost.com/business/1591838/motor-expo-bookings-up-10-orders-worthb56bn?newdesign=1 [accessed: June 18 2019].

Bangkok Post. 2019a. Graft panel an oddity. Bangkok Post September 16. https://www.bangkokpost.com/opinion/opinion/1751009/graft-panel-an-oddity [accessed: July 3 2020].

Bangkok Post. 2019b. Single-ticket foot-dragging. Bangkok Post June 18. https://www.bangkokpost.com/opinion/opinion/1697048/single-ticket-foot-dragging [accessed: June 19 2019].

Barter, P. 2011. Parking policy in Asian cities. Manila: Asian Development Bank. https://www.adb.org/publications/parking-policy-asian-cities [accessed: June 18 2019].

Beck, U. 1992. Risk society: towards a new modernity. Thousand Oaks, CA: SAGE.

Beevers, S.D. and D.C. Carslaw. 2005. The impact of congestion charging on vehicle emissions in London. Atmospheric Environment 39(1): 1-5. 
Behrsin, I. and C. Benner. 2017. Contested spaces and subjectivities of transit: political ecology of a bus rapid transit development in Oakland, California. Journal of Transport Geography 61: 95-103.

Bharadwaj, S., S. Ballare and M.K. Chandel. 2017. Impact of congestion on greenhouse gas emissions for road transport in Mumbai metropolitan region. Transportation Research Procedia 25: 3538-3551.

Burton, J. 2020. Report claims air pollution "kills thousands", costs billions annually. The Thaiger July 12. https://thethaiger.com/hot-news/environment/report-claims-air-pollution-kills-thousands-costsbillions-annually [accessed: July 14 2020].

Chalermpong, S. 2018. Transportation development and urbanization in the Bangkok Metropolitan Region. In Padawangi, R. (ed.) Routledge handbook of urbanization in Southeast Asia. London: Routledge. Pp. 288-306.

Chalermpong, S. and A. Ratanawaraha, A. 2020. Bangkok, Thailand. In Pojani, D. et al. (eds.) Parking: an international perspective. Amsterdam: Elsevier. Pp. 207-227.

Chankaew, P. and C. Setboonsarng. 2020. Smog forces Bangkok schools to shut, but respite in doubt due to crop burning. Reuters. January 21. https://www.reuters.com/article/us-thailand-environment-pollutionidUSKBN1ZK18E [accessed: July 14 2020].

Charoensin-o-larn, C. 2010. Thailand in 2009: unusual politics becomes usual. In Southeast Asian Affairs 2010. ISEAS-Yusof Ishak Institute. Pp. 303-331.

Collins, T.W. 2010. Marginalization, facilitation, and the production of unequal risk: the 2006 Paso del Norte floods. Antipode 42(2): 258-288.

Croci, E., S. Melandri and T. Molteni. 2011. Comparing mitigation policies in five large cities: London, New York City, Milan, Mexico City, and Bangkok. In Hoornweg, D., M. Freire, M.J. Lee, P. Bhada-Tata and B. Yuen (eds.). Cities and climate change: responding to an urgent agenda. Washington, DC: The World Bank. Pp. 55-85.

Daniere, A. 1995. Transportation planning and implementation in cities of the Third World: the case of Bangkok. Environment and Planning C: Government and Policy 13(1): 25-45.

Davivongs, V., M. Yokohari and Y. Hara. 2012. Neglected canals: deterioration of indigenous irrigation system by urbanization in the west peri-urban area of Bangkok Metropolitan Region. Water 4(1): 1227.

De Souza, F. F., T. Ochi and A. Hosono. 2018. Land readjustment: solving urban problems through innovative approach. Tokyo: JICA Research Institute.

Farrelly, N. 2013. Why democracy struggles: Thailand's elite coup culture. Australian Journal of International Affairs 67(3): 281-296.

Ferrer, A.L.C., A.M.T. Thomé and A.J. Scavarda. 2018. Sustainable urban infrastructure: a review. Resources, Conservation and Recycling 128: 360-372.

Fickling, D. 2018. We're running out of road. Bloomberg.com November 8. https://www.bloomberg.com/opinion/articles/2018-11-07/think-new-york-traffic-is-bad-try-bangkokor-jakarta [accessed: September 9 2019].

Graham, S. 2015. Life support: the political ecology of urban air. City 19(2-3): 192-215.

Graham, S. and S. Marvin. 2001. Splintering urbanism: networked infrastructures, technological mobilities and the urban condition. London: Routledge.

Harvey, D. 1973. Social justice and the city. Athens, GA: University of Georgia Press.

Heynen, N., M. Kaika and E. Swyngedouw. 2006. In the nature of cities: urban political ecology and the politics of urban metabolism. London: Routledge.

Hongtong, T. 2019. TDRI urges cheap fares for new rail routes. Bangkok Post June 10. https://www.bangkokpost.com/thailand/general/1692288/tdri-urges-cheap-fares-for-new-rail-routes [accessed: September 5 2019]. 
Jaensirisak, S., A. Sumalee, S. Ongkittikul, J.H.W. Ho and P. Luathep. 2010. Integrating congestion charging schemes and mass transit systems in Bangkok. Bangkok: Asian Transportation Research Society.

Janssen, P. 2018. Bangkok's bad air driven by car-making success. Asia Times April 21. https://www.asiatimes.com/2018/04/article/bangkoks-bad-air-driven-car-making-success/ [accessed: June 17 2019].

Jotikasthira, O. and M. Bangprapa. 2018. City to revive "Venice of the East" through new boat lines. Bangkok Post November 11. https://www.bangkokpost.com/thailand/general/1573950/city-to-revivevenice-of-the-east-through-new-boat-lines [accessed: June 24 2019].

Kakizaki, I. 2014. Trams, buses, and rails: the history of urban transport in Bangkok, 1886-2010. Chiang Mai: Silkworm Books.

Kębłowski, W. and D. Bassens. 2018. "All transport problems are essentially mathematical": the uneven resonance of academic transport and mobility knowledge in Brussels. Urban Geography 39(3): 413437.

Kębłowski, W., M. Van Criekingen and D. Bassens. 2019. Moving past the sustainable perspectives on transport: an attempt to mobilize critical urban transport studies with the right to the city. Transport Policy 81: 24-34.

Keil, R. 2003. Urban Political Ecology. Urban Geography 24(8): 723-738.

Khayesi, M., T. Litman, E. Vasconcellos, and W.V. Mitullah. 2017. Grounding urban walking and cycling research in a political economy framework. In Mitullah, W.V., M. Vanderschuren and M. Khayesi (eds.). Non-motorized transport integration into urban transport planning in Africa: London: Routledge. Pp. 224-235.

Kijmanawat, K. and P. Karoonkornsakul. 2016. Improving public bus service and non-motorized transport in Bangkok: a study for the Thailand Mobility NAMA. Bangkok: GIZ. https://www.thai-germancooperation.info/admin/uploads/publication/a1241af90ee0cc8c9d15de7d981f9167en.pdf [accessed: June 19 2019].

Klopp, J.M. 2012. Towards a political economy of transportation policy and practice in Nairobi. Urban Forum 23: 1-21.

Koglin, T. and T. Rye. 2014. The marginalization of bicycling in modernist urban transport planning. Journal of Transport and Health 1(4): 214-222.

Lefebvre, H. 1976(1973). The survival of capitalism: reproduction of the relations of production. New York: St Martin's Press.

Lefebvre, H. 1991(1974). The production of space. Oxford: Blackwell.

Legacy, C. 2016. Transforming transport planning in the postpolitical era. Urban Studies 53(14): 3108-3124.

Luathep, P., S. Jaensirisak, S. Ongkittikul and A. Sumalee. 2017. Planning for bus rerouting in Bangkok Metropolitan Region. Journal of the Eastern Asia Society for Transportation Studies 12: 2376-2391.

Macan-Markar, M. 2011. Environment-Thailand: "Bangkok ignored warnings". Inter Press Service November 3 November. http://www.ipsnews.net/2011/11/environment-thailand-bangkok-ignoredwarnings/ [accessed: June 19 2019].

Marks, D. 2011. Climate change and Thailand: impact and response. Contemporary Southeast Asia 33(2): 229-258.

Marks, D. 2015. The urban political ecology of the 2011 floods in Bangkok: the creation of uneven vulnerabilities. Pacific Affairs 88(3): 623-651.

Marks, D. 2019. Assembling the 2011 Thailand floods: Protecting farmers and inundating high-value industrial estates in a fragmented hydro-social territory. Political Geography 68: 66-76.

Marks, D. and D. Brown. 2014. City needs urgent mass transportation expansion. Bangkok Post September 30. http://www.bangkokpost.com/print/435063/ [accessed: June 24 2019]. 
Marks, D., J. Connell and F. Ferrara. 2020. Contested notions of disaster justice during the 2011 Bangkok Floods: unequal risk, unrest, and claims to the city. Asia Pacific Viewpoint 61(1): 19-36.

Marks, D. and L. Lebel. 2016. Disaster governance and the scalar politics of incomplete decentralization: fragmented and contested responses to the 2011 floods in Central Thailand. Habitat International 52: 57-66.

Marks, D. and J. Zhang. 2019. Circuits of power: environmental injustice from Bangkok's shopping malls to Laos' hydropower dams. Asia Pacific Viewpoint 60(3): 296-309.

Marsden, G. and L. Reardon. 2017. Questions of governance: rethinking the study of transportation policy. Transportation Research Part A: Policy and Practice. 101: 238-251.

Mattioli, G., C. Roberts, J. K. Steinberger and A. Brown. 2020. The political economy of car dependence: a systems of provision approach. Energy Research and Social Science. 66: 101486.

Monstadt, J. 2009. Conceptualizing the political ecology of urban infrastructures: insights from technology and urban studies. Environment and Planning A 41(8): 1924-1942.

Murray, M.J. 2009. Fire and ice: unnatural disasters and the disposable urban poor in post-apartheid Johannesburg. International Journal of Urban and Regional Research 33(1): 165-192.

Narupiti, S., A. Tippichai, P. Nanthachatchavankul, M. Sutjaritthanarak and S. Bakker. 2014. Thailand stocktaking report on sustainable transport and climate change: data, policy and monitoring.

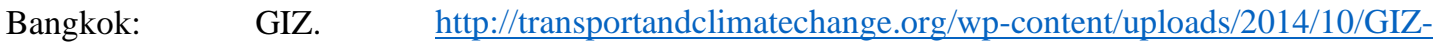
TCC_Thailand-Stocktaking-Report-September-2014.pdf [accessed: June 26 2019].

Ouyyanont, P. 1998. Bangkok and Thai economic development: aspects of change, 1820-1970. Ph.D. dissertation. Armidale, Australia: University of New England.

Phongpaichit, P. and C. Baker. 2015. Unequal Thailand: aspects of income, wealth and power. Singapore: NUS Press.

Phulsarikij, P. 2018. Bangkok congestion worsens. The Nation August 31. https://www.nationthailand.com/national/30353455 [accessed: September 9 2019].

Plumb, C. 1999. Bangkok. In Berry, J. and S. McGreal (eds) Cities in the Pacific rim, planning systems and property markets. London: E. \& F.N. Spon. Pp. 129-156.

Pujinda, P. 2016. Bangkok Metropolitan Region and its transportation system. Bangkok: Chulalongkorn University.

Pujinda, P. and S. Yupho. 2017. The paradoxical travel behavior of Bangkokians. Environment-Behaviour Proceedings Journal 2(5): 393-402.

Reynolds, C., Y. Nishizaki, J. Glassman, N. Farrelly, P. Busbarat, S. Lim, T. Haberkorn and P. Chachavalpongpun. 2012. Time's arrow and the burden of the past: a primer on the Thai un-state'. Sensate Journal.

Sabpaitoon, P. 2018. Groups seek to make Bangkok "walkable". Bangkok Post January 22. https://www.bangkokpost.com/thailand/general/1399814/groups-seek-to-make-bangkok-walkable [accessed: 24 June 2019].

Schlosberg, D. 2007. Defining environmental justice: theories, movements, and nature. Oxford: Oxford University Press.

Schwanen, T. 2016. Geographies of transport I: reinventing a field? Progress in Human Geography 40(1): 126-137.

Scruggs, G. 2015. How much public space does a city need? Nextcity.org. https://nextcity.org/daily/entry/how-much-public-space-does-a-city-need-UN-Habitat-joan-clos-50percent [accessed: June 14 2019].

Setchell, C.A. 1995. The growing environmental crisis in the world's mega-cities. Third World Planning Review 17(1): 1-18.

Shatkin, G. 2004. Globalization and local leadership: growth, power and politics in Thailand's Eastern Seaboard. International Journal of Urban and Regional Research 28(1): 11-26. 
Siu, J. 2017. The most expensive city in the world to park is no surprise. AutoGuide.com May 20. https://www.autoguide.com/auto-news/2017/05/the-most-expensive-city-for-parking-is-nosurprise.html [accessed: September 6 2019].

Swyngedouw, E. 2004. Social power and the urbanization of water: flows of power. Oxford: Oxford University Press.

Swyngedouw, E. 2006. Circulations and metabolisms: (hybrid) natures and (cyborg) cities. Science as Culture 15(2): 105-121.

Swyngedouw, E. 2010. Apocalypse forever? Theory, Culture \& Society 27(2-3): 213-232.

Swyngedouw, E. and N. Heynen. 2003. Urban political ecology, justice and the politics of scale. Antipode 35(5): 898-918.

Thaitakoo, D. and B. McGrath. 2010. Bangkok liquid perception: waterscape urbanism in the Chao Phraya River Delta and implications to climate change adaptation. In Shaw, R. and D. Thaitakoo. (eds.). Water communities. Bingley, UK: Emerald. Pp. 35-50.

The Nation. 2019a. Air pollution soars in Bangkok. The Nation October 22. https://www.nationthailand.com/news/30377639 [accessed: July 23 2020].

The Nation. 2019b. Bangkok's era of open-air buses to end in 2022. The Nation March 17. http://www.nationmultimedia.com/detail/national/30365954 [accessed: June 19 2019].

Thongphat, N. and P. Arporniem. 2017. Improving Bangkok's bus network. Bangkok Post September 13. https://www.bangkokpost.com/opinion/opinion/1323371/improving-bangkoks-bus-network [accessed: June 19 2019].

Véron, R. 2006. Remaking urban environments: the political ecology of air pollution in Delhi. Environment and Planning A 38(11): 2093-2109.

Wancharoen, S. 2019. Haze emphasizes need to fast-track train projects. Bangkok Post February 10. https://www.bangkokpost.com/business/1626734/haze-emphasises-need-to-fast-track-train-projects [accessed: 24 June 2019].

Wu, I. and D. Pojani. 2016. Obstacles to the creation of successful bus rapid transit systems: the case of Bangkok. Research in Transportation Economics 60: 44-53.

Zhang, J. 2019. Driving toward modernity: cars and the lives of the middle class in contemporary China. Ithaca: Cornell University Press. 


\section{Appendix 1: Interviewee Information}

\begin{tabular}{|c|c|c|}
\hline $\begin{array}{l}\text { Interview } \\
\text { Number }\end{array}$ & Identity & $\begin{array}{c}\text { Date } \\
\text { Interviewed (all } \\
\text { in 2018) } \\
\end{array}$ \\
\hline \#1 & Real Estate Developer \#1 & $7 / 19$ \\
\hline$\# 2$ & OTP senior official & $7 / 11$ \\
\hline \#3 & MoT consultant & $6 / 20$ \\
\hline \#4 & Real Estate Developer \#2 & $7 / 18$ \\
\hline \#5 & TDRI senior official & $7 / 11$ \\
\hline$\# 6$ & Chulalongkorn University Professor and government consultant & $7 / 16$ \\
\hline$\# 7$ & TDRI mid-level official & $7 / 18$ \\
\hline$\# 8$ & Senior BMA official & $7 / 19$ \\
\hline$\# 9$ & DLT senior official & $8 / 23$ \\
\hline$\# 10$ & Prachathai Reporter & $7 / 23$ \\
\hline$\# 11$ & International environmental think tank senior official & $6 / 21$ \\
\hline$\# 12$ & Voice TV host & $7 / 2$ \\
\hline$\# 13$ & Freelance journalist & $7 / 26$ \\
\hline$\# 14$ & Bangkok Mass Transit Authority (BMTA) senior official & $7 / 25$ \\
\hline$\# 15$ & Former Minister of Transportation & $7 / 26$ \\
\hline$\# 16$ & Bangkok Bus Club Representative & $7 / 18$ \\
\hline$\# 17$ & Bangkok May Day Group Representative & $7 / 17$ \\
\hline$\# 18$ & Renown Bangkok architect who works on urban transportation & $6 / 14$ \\
\hline$\# 19$ & $\begin{array}{l}\text { Transportation Engineering Professor at King Mongkut's University of } \\
\text { Technology Thonburi }\end{array}$ & $8 / 7$ \\
\hline$\# 20$ & International aid agency who conducted report on Bangkok's transportation & $7 / 19$ \\
\hline \#21 & Leading civil society activist who frequently takes the bus & $7 / 20$ \\
\hline
\end{tabular}

